\title{
Mn Depletion Behavior at Oxide/matrix Interface in Low Oxygen Weld Metal of Low Carbon Steel
}

\author{
Ryuichi Homma $^{1)^{*}}$, Genichi Shigesato ${ }^{2)}$, Masaaki FujIokA ${ }^{2)}$, Kota Kadoi $^{3)}$ and Hiroshige Inoue ${ }^{3)}$ \\ 1) East Nippon Research and Development Laboratories, Nippon Steel Corporation \\ 2) Steel Research Laboratories, Nippon Steel Corporation \\ 3) Joining \& Welding Research Institute, Osaka University
}

Abstract: The structure of the oxide as a nucleus for intragranular ferrite formation in the low $\mathrm{O}$ weld metal and the formation mechanism of Mn depleted zone (MDZ) at the oxide/matrix interface were studied using liquid-tin quenched specimens at high-temperature conditions during laser welding of low carbon $\mathrm{Ti}$ added steel. At a high temperature of $1720 \mathrm{~K}, \mathrm{MDZ}$ is formed around the complex oxides of (Ti,Mn) ${ }_{3} \mathrm{O}_{5}$, $(\mathrm{Ti}, \mathrm{Mn})_{2} \mathrm{O}_{3}$, and liquid phase oxides (containing Si, Mn, Ti, and S). The width of the MDZ increases with cooling, and at low temperatures $(1275 \mathrm{~K}) \mathrm{MDZ}$ is formed around the complex oxide consisting mainly of $(\mathrm{Ti}, \mathrm{Mn})_{2} \mathrm{O}_{3}$ with $\mathrm{MnS}$ and Si-Mn oxides. These MDZs are formed all around the complex oxides, regardless of the kind of oxide. The formation of MDZs is considered to promote the ferrite transformation around the oxides. The equilibrium $\mathrm{Mn}$ concentration in each of the oxide phases increases during the cooling process and the thermodynamically stable phase changes from $(\mathrm{Ti}, \mathrm{Mn})_{3} \mathrm{O}_{5}$ with a low equilibrium Mn concentration to (Ti,Mn) ${ }_{2} \mathrm{O}_{3}$ with a high equilibrium $\mathrm{Mn}$ concentration, which drives the diffusion of $\mathrm{Mn}$ from the matrix phase to the oxide. In this process, MDZs are formed all around the complex oxides.

Keywords: intragranular ferrite; Mn depleted zone; Ti oxide; laser weld metal.

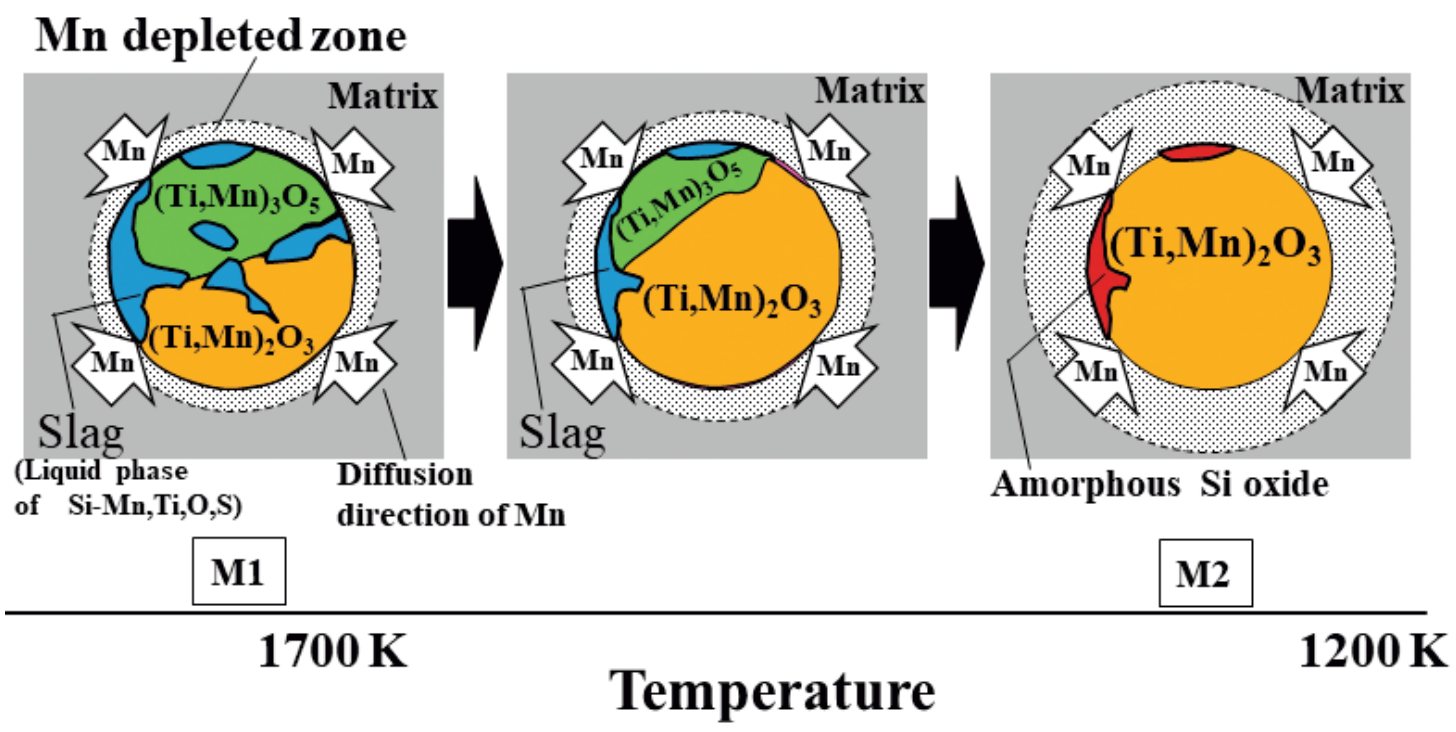

Received on Aug. 2, 2021; Accepted on Oct. 26, 2021; J-STAGE Advance published on Dec. 3, 2021

* Corresponding author. E-mail: homma.594.ryuichi@jp.nipponsteel.com, Address: Nippon Steel Corporation, 3 Hikari Kashima Ibaraki 314-0014 


\title{
低炭素鋼の低酸素濃度溶接金属における 酸化物 / 母相界面の Mn 欠乏挙動
}

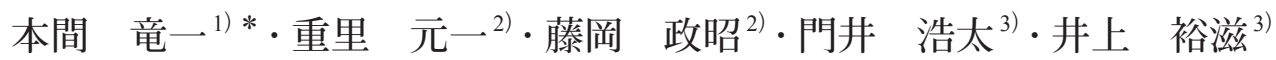

Mn Depletion Behavior at Oxide/matrix Interface in Low Oxygen Weld Metal of Low Carbon Steel

Ryuichi Homma, Genichi Shigesato, Masaaki Fujora, Kota Kador and Hiroshige Inoue

\section{1. 緒言}

低炭素鋼溶接金属組織の勒性向上を目的とした組織微 細化には粒内フェライトの活用が有効である ${ }^{1,2)}$ 。穴のた め, 粒内フェライトの生成については, 粒内フェライトの 核として有効な第二相 ${ }^{3-7)}$, 添加元素の影響 ${ }^{8,9)}$, 溶接方法 の影響 ${ }^{10)}$ など, 多くの関連研究がある。溶接金属の粒内 フェライトは主に酸化物上に核生成することから, 粒内 フェライトの核生成に有効な酸化物を高密度に分散させ ることが金属組織の微細化には効果的である。これまで溶 接金属の粒内フェライト核として有効な酸化物はGlaxite $\left(\mathrm{MnO} \cdot \mathrm{Al}_{2} \mathrm{O}_{3}\right)^{3,11,12)}, \mathrm{TiO}^{3,13)}, \mathrm{MnTi}_{2} \mathrm{O}_{4}{ }^{14)}$ といった $\mathrm{Mn}, \mathrm{Ti}$ 含 む酸化物が知られており, これらの酸化物はフェライトと 格子整合性が良好であることでフェライトが核生成しやす いと言われている。一方, 溶接熱影響部においては MnSが 生成する酸化物の周囲で $\mathrm{Mn}$ 濃度の低下領域である $\mathrm{Mn}$ 欠 乏層 (Mn depleted zone, 以下 MDZと記す) が生じ, 粒内フェ ライトが生成しやすいことが知られている ${ }^{15-19)}$ 。このよう にフェライトと格子整合性が良好な酸化物やMDZの形成 を促進する酸化物を生成させることが, 低炭素鋼溶接部の 組織微細化には重要であると考えられる。

低炭素鋼溶接金属の粒内フェライト生成に関する研究 は, 主にO濃度が $200-1000$ ppmのアーク溶接金属中の粒 内フェライト生成に関するものがほとんどである。一方, 電子ビーム溶接金属やレーザ溶接金属では，O濃度がアー ク溶接金属の $1 / 10$ 以下となるため, このような低 $O$ 濃度の 溶接金属では，一般的に酸化物を核に生成する粒内フェラ イトを利用した金属組織の微細化は難しいとされてきた。 しかしながら, 著者らは電子ビーム溶接の低 $\mathrm{O}$ 濃度の溶接 金属中での S P Siが非晶質 Si-Mn 酸化物上での $\mathrm{MnS}$ の生成 を促進し, これが粒内フェライト生成を促進することを示
した ${ }^{20)}$ 。また, Ti は低O濃度の溶接金属中にTi酸化物を生 成させ, 粒内フェライト生成の促進に有効であることを報 告している ${ }^{21,22)}$ 。これらの低 $\mathrm{O}$ 濃度の溶接金属中での粒内 フェライトの生成については, 酸化物/母相界面で顕著な MDZが形成し, このMDZによって粒内フェライトの生成 が促進されると考えられている ${ }^{19,21)}$

このような粒内フェライトの生成を促進する MDZの形 成は, 大きく分けて2つの機構が考えられている。一つは 酸化物上に MnS や TiNなどが生成し, それに伴いこれらの 複合酸化物に母相から Mnが拡散し, 複合酸化物の周囲に $\mathrm{MDZ}$ が生成するという機構であり,もう一つは, MnSや TiNの生成, 成長に関係なく, 母相から酸化物へ Mnが拡散 し, MDZが形成するという機構である。前者の機構にお いて重要である $\mathrm{MnS}$ が生成しやすい酸化物としては $\mathrm{Ti}_{2} \mathrm{O}_{3}$ を含む複合酸化物 ${ }^{15,23)}, \mathrm{Si}-\mathrm{Mn}$ 酸化物 ${ }^{16,18,20)}, \mathrm{Al}_{2} \mathrm{O}_{3}{ }^{17)}$ が知 られており, これらのうち Ti 酸化物やSi-Mn酸化物は, 母 相の固相線直下の高温で酸化物融体となっており, その 酸化物融体が $\mathrm{S}$ を多く含有しているため, $\mathrm{MnS}$ の有効な核 生成サイトとなる ${ }^{24-26)}$ 。このような酸化物上に $\mathrm{MnS}$ が生 成, 成長する際, Mnが母相から MnSへ拡散し, 酸化物/母 相界面でMDZが形成すると考えられている ${ }^{24)}$ 。一方, Ti 酸化物上へTiNが生成する際は, Ti酸化物中の Mn 固溶量 が増加して Mnが母相から Ti酸化物へ拡散し, MDZの生 成を促進すると考えられている27)。後者の機構において は, Ti 酸化物 ${ }^{28,29)}$ p Si-Mn酸化物 ${ }^{30)}$ の周囲では, 酸化物上 にMnSやTiNが存在しなくても MDZが生じることが確認 されている。さらに, Kosekiらは熱力学計算により冷却過 程の母相中で安定相が Mullite $\left(2 \mathrm{SiO}_{2} \cdot 3 \mathrm{Al}_{2} \mathrm{O}_{3}\right)$ から Galaxite $\left(\mathrm{MnO} \cdot \mathrm{Al}_{2} \mathrm{O}_{3}\right)$ に変化する際, Galaxiteの形成には母相から GalaxiteへMnが拡散する必要があり, このとき MDZが形 成すると考察している ${ }^{31}$ 。このように冷却中の酸化物の安

2021年8月2日受付２021年10月26日受理２021年12月3日J-STAGE早期公開 (Received on Aug. 2, 2021; Accepted on Oct. 26, 2021; J-STAGE Advance published on Dec. 3, 2021)

1）日本製鉄 (株) 技術開発本部東日本技術研究部（East Nippon Research and Development Laboratories, Nippon Steel Corporation)

2) 日本製鉄 (株) 技術開発本部鉄鋼研究所 (Steel Research Laboratories, Nippon Steel Corporation)

3) 大阪大学接合科学研究所 (Joining \& Welding Research Institute, Osaka University)

* Corresponding author. E-mail: homma.594.ryuichi@jp.nipponsteel.com, Address: Nippon Steel Corporation, 3 Hikari Kashima Ibaraki $314-0014$ 
定相の変化に伴い，母相から酸化物へ Mnが拡散する過程 でMDZが形成する可能性が指摘されているが, 高温での 酸化物の状態を実験的に確認することは難しく, 詳細な機 構に関しては不明な点が多い。

著者らは ${ }^{20,22)}$, これまで電子ビーム溶接の低 $\mathrm{O}$ 濃度の溶 接金属中において, 酸化物/母相界面で生じた MDZが粒 内フェライトの生成を促進させることを報告してきたが， MDZの形成挙動については明かではなかった。そこで本 報では, 低 $\mathrm{O}$ 濃度の溶接金属中の酸化物/母相界面で生じ るMDZの形成機構を明らかにすることを目的として，低 炭素Ti添加鋼を用いて溶接時の高温状態を急冷凍結し, 酸 化物の構造および酸化物/母相界面の Mn 濃度分布を詳細 に調査した。これに加え母相と酸化物の熱力学計算による 安定相の変化も考慮し, 低O濃度の溶接金属中の MDZ形 成機構を検討した。なお，本報での低 $\mathrm{O}$ 濃度の溶接金属の 检討にはレーザ溶接法を適用し，これまでの検討に使用し てきた電子ビーム溶接と同様のビード形状, 冷却速度打よ び溶接金属の O濃度となるように, レーザ溶接法の溶接条 件を調整した。

\section{2. 実験方法}

供試鋼の化学成分は $\mathrm{Fe}-0.08$ mass $\% \mathrm{C}-0.3$ mass $\% \mathrm{Si}-2.0$ mass\% $\%$ Mn -0.0008 mass\% S - 0.01 mass\% Ti - 0.004 mass\% $\mathrm{N}$ (以下，単純に\%と表記する) である。供試鋼は真空溶 解した $20 \mathrm{~kg}$ 鋳片を加熱温度 $1373 \mathrm{~K}$, 最終圧延温度 $1128 \mathrm{~K}$ で熱間圧延して板厚 $15 \mathrm{~mm}$ に仕上げた。長さ $120 \mathrm{~mm}$, 幅 $50 \mathrm{~mm}$, 板厚 $12 \mathrm{~mm}$ の試験片を切り出し, ファイバーレー ザ（波長 $1070 \mathrm{~nm}$ ）を用いてフィラーワイヤーを使用せず 溶接長約 $80 \mathrm{~mm}$ のビードオン溶接を行った。レーザ溶接は 出力 : $3 \mathrm{~kW}$, 溶接速度 : $0.2 \mathrm{~m} / \mathrm{min}$, 焦点長さ : $300 \mathrm{~mm}$, 焦 点位置: 試料表面から上方に $5 \mathrm{~mm}$, シールドガス: $\mathrm{Ar}$ $2 \% \mathrm{O}_{2}$, 流量 $20 \mathrm{~L} / \mathrm{min}$ の条件で実施した。溶接金属の $\mathrm{O}$ 濃度 は44 ppmであった。レーザ溶接の溶融池後端部の温度測定 は二色測温法を用いた ${ }^{32}$ 。温度測定は溶接面の鉛直方向か
ら実施した。溶接金属の急冷凍結には, 液体 Sn急冷法を用 いた ${ }^{33-35)}$ 。トーチ後方・直上より約 $600 \mathrm{~K} て ゙$ 溶融した $\mathrm{Sn}$ レーザ溶接終了と同時に素早く大量に注ぎ, 凝固中および 冷却中の溶接金属を急冷凍結した。なお, 液体 $\mathrm{Sn}$ 急冷法の 冷却速度は $10^{4} \mathrm{~K} / \mathrm{s}$ 以上と推定される ${ }^{33)}$ 。

二色測温法により測定された溶融池後端部の温度測定結 果をFig.1 (a) に示す。なお, Fig.1 (a) の横軸は溶融池後端 の固相/液相界面 (以下, S/L interface と示す) からの距離を 示す。また, 溶融池後端の $\mathrm{S} / \mathrm{L}$ interfaceからの距離と温度の 関係は，式（1）で表される。なお $\mathrm{S} / \mathrm{L}$ interfaceの FactSage ${ }^{\mathrm{TM}}$ (Ver.7.3, データセットはFS stel, FT oxid) ${ }^{36)}$ で計算した液 相線温度 $(1789 \mathrm{~K})$ とした。

$T_{S}=-139 \cdot d+1789$

$T_{s}:$ 表面温度 $(\mathrm{K}), d: \mathrm{S} / \mathrm{L}$ interface からの距離 $(\mathrm{mm})$

金属組織観察用試験片の採取位置はFig.1（b）に示すよ うに, 急冷凍結時の温度が液相線温度 $(1789 \mathrm{~K})$ 直下であ る高温部 $(\mathrm{M} 1)$ とオーステナイト/フェライト変態点 $\left(\mathrm{A}_{\mathrm{e} 3}\right.$ : $1090 \mathrm{~K})$ 直上でフェライト析出前である低温部（M2），お よび室温まで冷却された部位（以下，室温部と示す）の 3筒所とした。高温部 (M1) の採取位置は式 (1)により 温度が $1720 \mathrm{~K}$ となる $\mathrm{S} / \mathrm{L}$ interfaceから $0.5 \mathrm{~mm}$ とし, 低温 部（M2）の採取位置は式（1）により温度が $1275 \mathrm{~K}$ となる $\mathrm{S} / \mathrm{L}$ interfaceから $3.7 \mathrm{~mm}$ の位置とした。また, 室温部は $\mathrm{S} / \mathrm{L}$ interfaceから十分離れた位置から試料を採取した。

溶接金属の組織観察は全て試料表面側から実施した。光 学顕微鏡用試料は表面を鏡面研磨し, ナイタールエッチン グした後に観察した。溶接金属中の酸化物の観察は電界放 出型透過型電子顕微鏡 (FE-TEM) を用いた。試料作製には レプリカ法 (Cuメッシュ) と Focused Ion Beam (FIB) 法を 用いた。化学組成はTEMに付属のエネルギー分散型X線 分光法 (Energy Dispersive X-Ray Spectroscopy：EDS) によ り測定した。 (a)

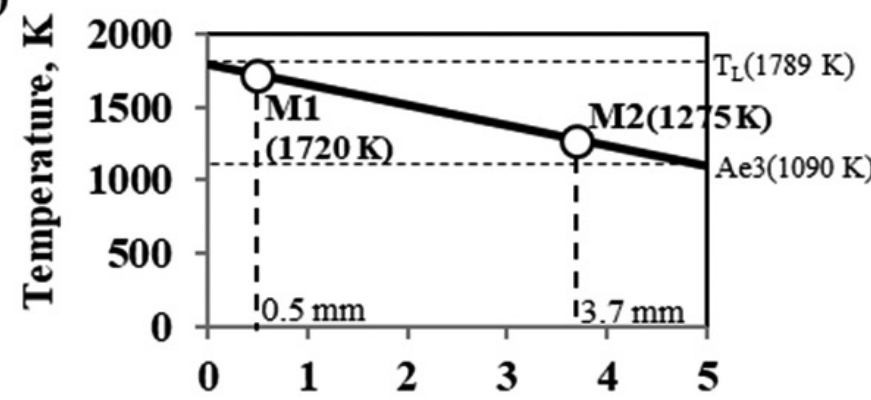

(b)

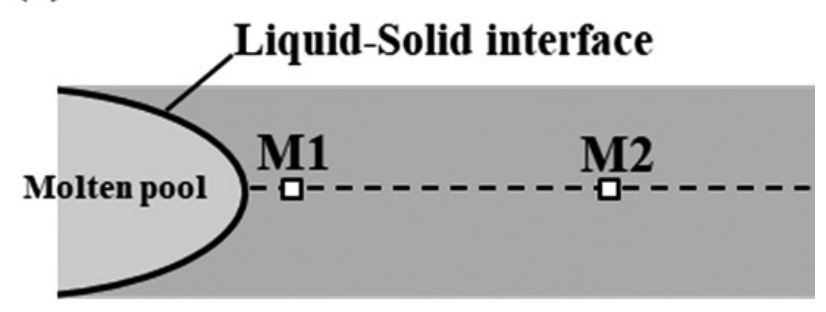

Distance from L/S interface, $\mathrm{mm}$

Fig. 1. (a) Relationship between distance from L/S interface and temperature in laser weld joint, and (b) sampling position of M1 and M2 in liquid-tin quenched specimen. 


\section{3. 実験結果}

\section{$3 \cdot 1$ 室温部の金属組織と酸化物}

室温部のミクロ組織を Fig.2 に示す。塊状のベイナイト と粒内フェライト (矢印) が認められる。粒内フェライト はアスペクト比の比較的大きな針状で, 短径が $1-3 \mu \mathrm{m}$, 長 径が $10 \mu \mathrm{m}$ 程度であり, ベイナイトよりも微細である。

溶接金属中で観察される代表的な酸化物の TEM 観察結 果をFig.3に示す。Fig.3 (a) の明視野像では酸化物の左側 外縁部にコントラストの異なる部分が存在しており複合 酸化物であることが示唆される。Fig.3 (b) に示す点 1 の EDS 結果からは Ti, Mn, O が検出され, 電子線回折像から $\mathrm{Ti}_{2} \mathrm{O}_{3}$ (Trigonal) と同定された。Mnを含有しており $\mathrm{MnTiO}_{3}$ (Trigonal) の可能性もあるが, 結晶構造がほぼ同じで電子 回折像からは区別が難しいため, 以下ではこのような $\mathrm{Mn}$ を含んだ $\mathrm{Ti}_{2} \mathrm{O}_{3}$ を $(\mathrm{Ti}, \mathrm{Mn})_{2} \mathrm{O}_{3}$ と表記する。Fig.3 (c) に示す 点 2 の EDS 結果からは $\mathrm{Si}, \mathrm{O}$ が高く検出され電子回折像は
ハローパターンを示していることから, 点 2 は非晶質 $\mathrm{Si}$ 酸 化物であることがわかる。その他の酸化物も同様の複合酸 化物であることが確認された。このようにレーザ溶接金属

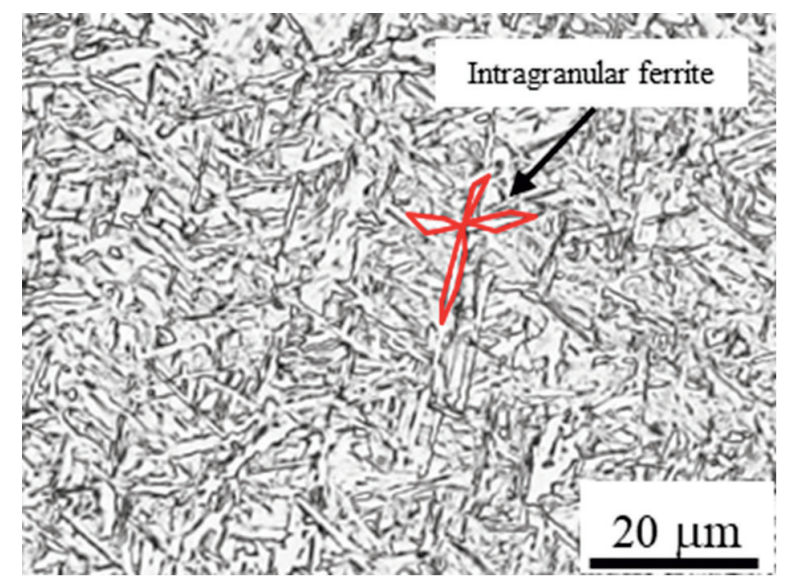

Fig. 2. Optical micrograph of laser weld metal at room temperature. (Online version in color.)

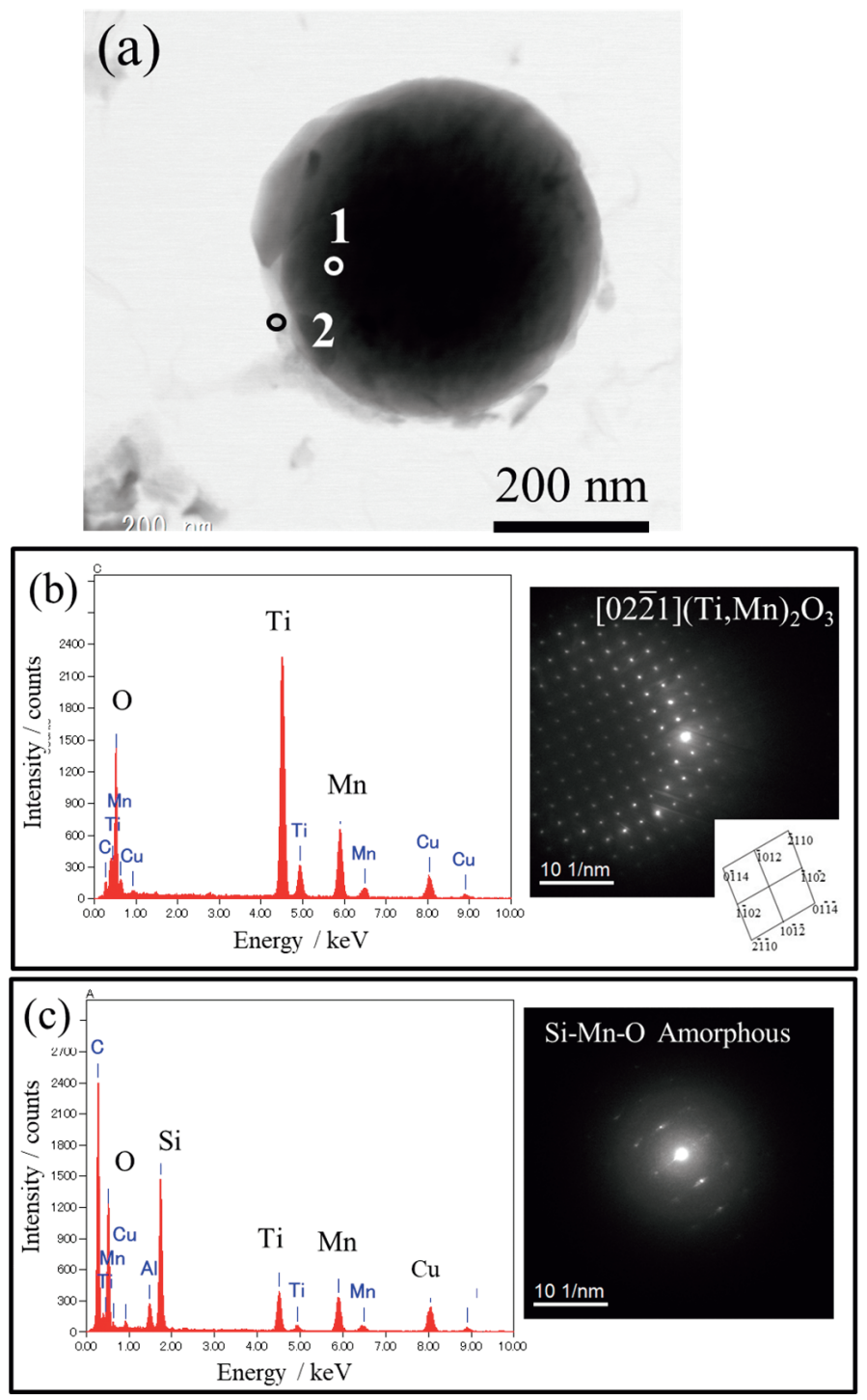

Fig. 3. TEM image and analysis of the oxide in laser weld metal at room temperature (a) bright field image, (b) diffraction pattern of point 1 , and (c) diffraction pattern of point 2. (Online version in color.) 
の室温部では, 微細な粒内フェライトが生成し, 酸化物と して $(\mathrm{Ti}, \mathrm{Mn})_{2} \mathrm{O}_{3}$ と非晶質 $\mathrm{Si}$ 酸化物の複合酸化物が存在し ていることから，これらの複合酸化物が粒内フェライトの 核生成を促進していることが推察できる。なお，このよう な金属組織や酸化物は, これまで著者らが検討してきた電 子ビーム溶接金属における低 $\mathrm{O}$ 濃度の溶接金属で観察され る金属組織や酸化物とほぼ同じであることから ${ }^{20,22)}$, 粒内 フェライトの生成機構も同じであると考えられる。

\section{$3 \cdot 2$ 高温部の酸化物形態}

Fig.4に高温部 $(1720 \mathrm{~K})$ の M1 位置で確認された酸化物 の TEM 観察結果を示す。Fig.4 (a) に示す明視野像では酸 化物内部の回折コントラストが複雑な形態を呈しており, 複数の結晶構造が存在していることが示唆される。Fig.4 (b)に示す点1のEDS 結果ではTi, Mn, Oが検出されて おり, 電子線回折像から $\mathrm{Ti}_{3} \mathrm{O}_{5}$ (Orthorhombic) と同定され た。以下ではこのような $\mathrm{Mn}$ を含む $\mathrm{Ti}_{3} \mathrm{O}_{5}$ を $(\mathrm{Ti}, \mathrm{Mn})_{3} \mathrm{O}_{5}$ と表
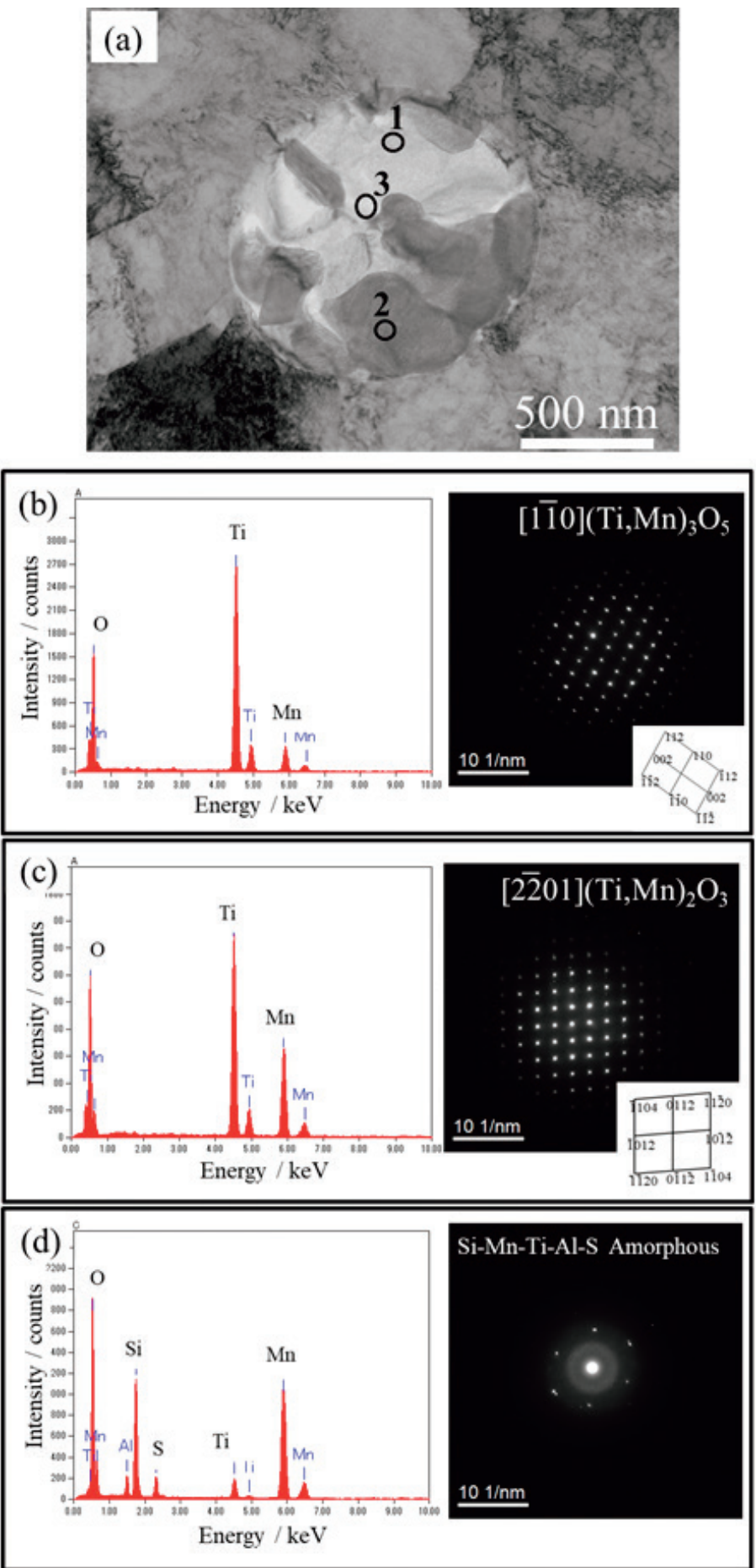

Fig. 4. TEM image and analysis of oxide in M1 specimen. (a) Bright field image, (b) EDS analysis and diffraction pattern of point 1, (c) EDS analysis and diffraction pattern of point 2, and (d) EDS analysis and diffraction pattern of point 3. (Online version in color.) 
記する。Fig.4 (c) に示す点2の EDS 結果では点 1 と同様に $\mathrm{Ti}, \mathrm{Mn}, \mathrm{O}$ が検出されているが, 電子線回折像から点 2 は $(\mathrm{Ti}, \mathrm{Mn})_{2} \mathrm{O}_{3}$ (Trigonal) と同定された。Ti と $\mathrm{Mn} の$ 検出量の比 では $(\mathrm{Ti}, \mathrm{Mn})_{3} \mathrm{O}_{5}$ が $\mathrm{Mn} / \mathrm{Ti}=0.12$ に対して $(\mathrm{Ti}, \mathrm{Mn})_{2} \mathrm{O}_{3}$ は $\mathrm{Mn} /$ $\mathrm{Ti}=0.41$ であり, $(\mathrm{Ti}, \mathrm{Mn})_{2} \mathrm{O}_{3}$ の方が明らかに $\mathrm{Mn}$ 濃度が高 い。Fig.4 (d) に示す点 3 の EDS 結果では Si, Mn, Oが検出 され, さらに微量の $\mathrm{Ti}, \mathrm{Al}, \mathrm{S}$ が検出されている。電子線回 折像はハローパターンを示しており, 点 3 は非晶質 Si-Mn 酸化物（微量の $\mathrm{Ti}, \mathrm{Al}, \mathrm{S}$ を含む）であることがわかる。こ のように高温部 $(1720 \mathrm{~K})$ で確認される酸化物の構成は, Fig.3で示した室温部で確認された酸化物の構成とは明か に異なる。ただし，高温部で観察されるその他の酸化物も 含めて, MnS は観察されず，また母相と格子整合性が良い $\mathrm{TiO}$ な゙の酸化物は観察されなかった。

Fig.5 に元素マッピング結果を示す。Oは概ね酸化物全体 に分布している。Si は酸化物中に不定形に分布している。 $\mathrm{Ti}$ は $\mathrm{Si}$ の検出領域以外の概ね酸化物全体で検出されてい る。 $\mathrm{Si}$ は $(\mathrm{Ti}, \mathrm{Mn})_{3} \mathrm{O}_{5}$ や $(\mathrm{Ti}, \mathrm{Mn})_{2} \mathrm{O}_{3}$ には固溶しないことから, $\mathrm{Si}$ の検出領域が非晶質 Si-Mn酸化物に対応し，それ以外は Ti酸化物であると考えられる。酸化物左側外縁部にはSが 検出されており, 非晶質 Si-Mn酸化物の一部にはSが含ま れている。Mnは酸化物の左上の領域で検出量が低く, 右
下の領域で比較的高く検出されている。Fig.4の結果も合 せて考えると, 酸化物の左上部分にあたる $\mathrm{Ti}$ の検出量が高 くMnの検出量が低い領域で非晶質 Si-Mn酸化物以外の領 域が $(\mathrm{Ti}, \mathrm{Mn})_{3} \mathrm{O}_{5}$, 酸化物の右下部分で $\mathrm{Ti}$ と $\mathrm{Mn}$ の検出量が 高く非晶質 $\mathrm{Si}-\mathrm{Mn}$ 酸化物以外の領域が $(\mathrm{Ti}, \mathrm{Mn})_{2} \mathrm{O}_{3}$ であると 考えられる。以上より, 高温部 $(1720 \mathrm{~K})$ では $(\mathrm{Ti}, \mathrm{Mn})_{3} \mathrm{O}_{5}$, $(\mathrm{Ti}, \mathrm{Mn})_{2} \mathrm{O}_{3}$, 非晶質 $\mathrm{Si}-\mathrm{Mn}$ 酸化物（微量の Ti, $\mathrm{Al}, \mathrm{S}$ を含む) から構成される複合酸化物が存在している。

Fig.5で元素分布を示した高温部 $(1720 \mathrm{~K})$ の複合酸化 物の周囲で測定した酸化物/母相界面近傍の Mn 濃度分布 をFig.6に示す。Mn濃度の測定はFig.6 (a) に示す5箇所で 行った。線分 $\mathrm{A}$, 線分 $\mathrm{B}$ の酸化物側は $(\mathrm{Ti}, \mathrm{Mn})_{3} \mathrm{O}_{5}$, 線分 $\mathrm{C}$, 線分 Dの酸化物側は $(\mathrm{Ti}, \mathrm{Mn})_{2} \mathrm{O}_{3}$, 線分 $\mathrm{E}$ の酸化物側は非晶 質 Si-Mn酸化物である。いずれの位置においても $\mathrm{MnS}$ は認 められなかった。Fig.6 (b) に各測定箇所における Mn濃度 分布を示す。Fig.6 (b) において酸化物/母相の界面が横軸 0 であり，横軸十側は母相側，一側は酸化物側の值である。 線分 $\mathrm{A}-\mathrm{E}$ の Mn濃度はいずれも似たような分布を示して おり，固相線温度直下にも関わらず，既に明瞭な MDZが形 成している。酸化物/母相の界面から母相側へ20 nm付近 で $\mathrm{Mn}$ 濃度が最も低下し約 $1.0 \mathrm{~mol} \%$ となる。酸化物/母相 界面から離れるにつれて Mn濃度は上昇し, 酸化物/母相界
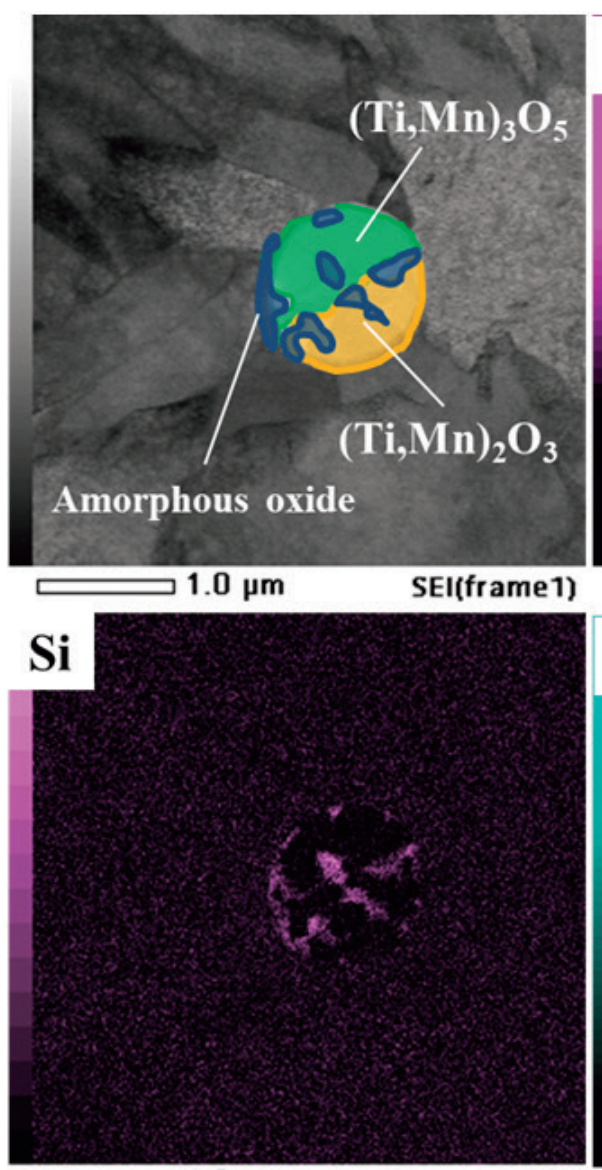

$1.0 \mu \mathrm{m}$

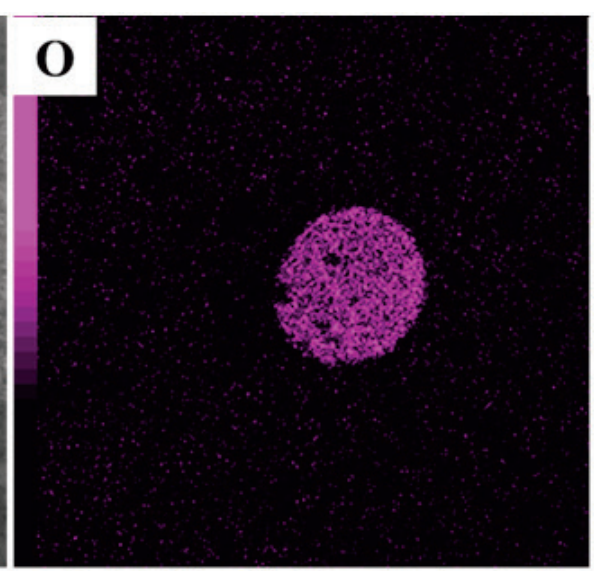

$1.0 \mu \mathrm{m}$

O K

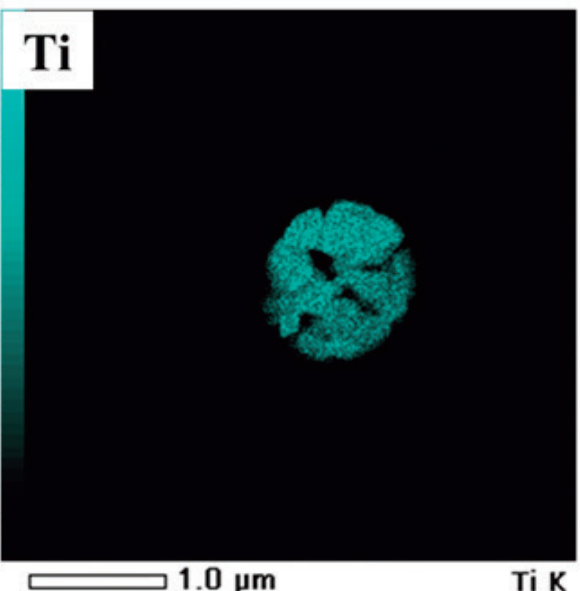

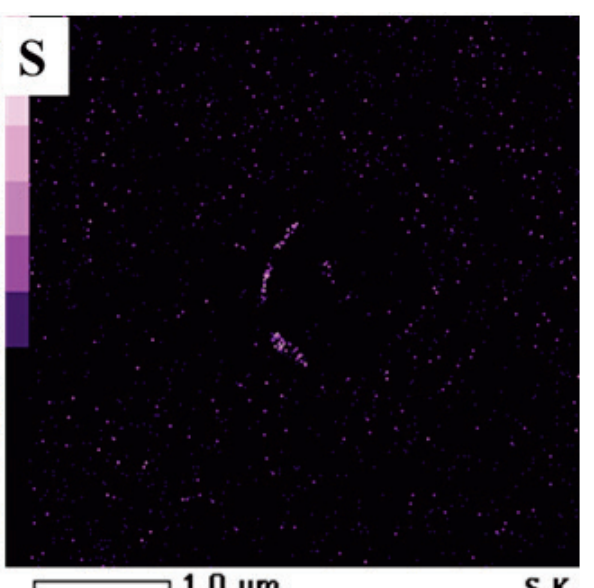

Mn

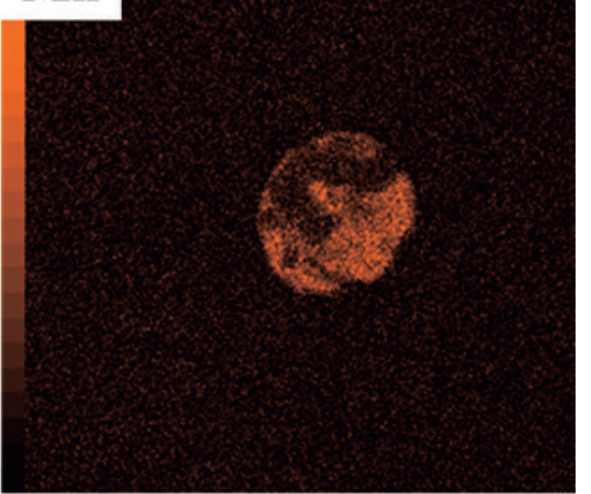

$\mathrm{MnK}$

Fig. 5. TEM image and EDS elemental mapping of oxide in M1 specimen. (Online version in color.) 
面から $80 \mathrm{~nm}$ 付近で $\mathrm{Mn}$ 濃度の上昇が止まり, $\mathrm{Mn}$ 濃度は 2.2 $\mathrm{mol} \%$ 程度で一定となる。一定となる $\mathrm{Mn}$ 濃度 $2.2 \mathrm{~mol} \%$ を母 相の Mn 濃度として, Mn濃度の低下範囲をMDZ幅と考え ると, 高温部 $(1720 \mathrm{~K})$ の MDZ幅は $80 \mathrm{~nm}$ 程度である。一方, TiやSi はMnのように酸化物/母相界面付近での濃度低下 は確認されなかった。このように高温部 $(1720 \mathrm{~K})$ では酸 化物 /母相界面の母相側の Mn 濃度は, 母相の Mn 濃度より も約 $1.2 \mathrm{~mol} \%$ 低下し, 幅 $80 \mathrm{~nm}$ 程度の MDZが認められる。 また,これらの MDZは酸化物の種類によらず, 複合酸化物 の周囲全体に形成している。

\section{$3 \cdot 3$ 低温部の酸化物形態}

Fig.7に低温部 $(1275 \mathrm{~K})$ の M2 位置で確認された酸化物 の TEM 観察結果を示す。Fig.7 (a) に示す明視野像ではい くつかのコントラストに分かれており, 複合酸化物である ことが示唆される。Fig.7（b）に示すようにEDS結果では $\mathrm{Ti}, \mathrm{Mn}, \mathrm{O}$ が検出され, 電子線回折像から点 1 は $(\mathrm{Ti}, \mathrm{Mn})_{2} \mathrm{O}_{3}$ (Trigonal) である。Fig.7 (c) に示す点 2 は, 電子回折像によ り点 1 と同じ $(\mathrm{Ti}, \mathrm{Mn})_{2} \mathrm{O}_{3}$ (Trigonal) であるが, EDS 結果で は微量にSiが検出されており, 周囲とのコントラストの違 いは試料表層部に非晶質 Si 酸化物が存在しているためと 推察される。一方, 酸化物の右側の試料表面に近い部分で コントラストが異なるのはFIB 試料作製時にダメージを受 けたためであり, 酸化物相と化学成分は隣接する Fig.7 (b) と同じであった。Fig.7 (d) に示すEDS 結果と電子線回折像 から点 3 は MnS (Cubic) と同定された。供試鋼のS濃度は 極めて低いが，このように Ti酸化物に微量の MnS が生成 する場合がしばしば認められる。以上より低温部 $(1275 \mathrm{~K})$ の酸化物は $(\mathrm{Ti}, \mathrm{Mn})_{2} \mathrm{O}_{3}$ を主体に微量の $\mathrm{MnS}$ や非晶質 $\mathrm{Si}$ 酸 化物が生成した複合酸化物であることが確認された。すな わち, 低温部 $(1275 \mathrm{~K})$ で確認される酸化物の構成は, Fig.4 で示した高温部の酸化物の構成とは異なっており, Fig.3で
示した室温部の酸化物の構成に近くなっている。また，低 温部 $(1275 \mathrm{~K})$ で観察されるその他の酸化物も含めて, 母相 と格子整合性が良い $\mathrm{TiO}$ な゙の酸化物は確認されなかった。

Fig.8 に低温部 $(1275 \mathrm{~K})$ の複合酸化物の周囲で測定した 酸化物/母相界面近傍の Mn 濃度分布を示す。Mn濃度の測 定はFig.8 (a) に示す3箇所で行った。線分 A, 線分 Bの界 面付近の酸化物は $(\mathrm{Ti}, \mathrm{Mn})_{2} \mathrm{O}_{3}$, 線分 $\mathrm{C}$ の界面付近には $\mathrm{MnS}$ が存在する。Fig.8 (b) に各測定箇所における Mn 濃度分 布を示す。Fig.6 (b) と同様に酸化物/母相の界面が横軸 0 である。いずれの測定位置においても酸化物/母相界面の 母相側 $20 \mathrm{~nm}$ 付近で $\mathrm{Mn}$ 濃度が最も低下し, Mn 濃度は 1.0 $\mathrm{mol} \%$ 程度となっており, 母相の $\mathrm{Mn}$ 濃度よりも約 $1.3 \mathrm{~mol} \%$ 低下している。また, 酸化物/母相界面から離れるにつれて $\mathrm{Mn}$ 濃度は上昇し, 酸化物/母相界面から約 $200 \mathrm{~nm}$ 付近で 母相の Mn 濃度となることから, 低温部 $(1275 \mathrm{~K})$ の MDZ の幅は約 $200 \mathrm{~nm}$ であり, 高温部 $(1720 \mathrm{~K})$ の MDZの幅に比 べて遙かに大きくなっている。さらに高温部 $(1720 \mathrm{~K})$ と 同様に低温部 $(1275 \mathrm{~K})$ の MDZは酸化物の種類によらず, 複合酸化物の周囲全体に形成している。

\section{4. 考察}

\section{$4 \cdot 1$ 溶接金属中の酸化物形成過程}

溶接金属中で生成する酸化物の形成過程を推測するため 熱力学計算を実施した。計算にはFactSage ${ }^{\mathrm{TM}}($ Ver.7.3, デー タセットはFS stel, FT oxid) ${ }^{36)}$ を用いた。Fig.9に溶接金属 中の安定相を計算した結果を示す。成分系は Fe - $0.08 \% \mathrm{C}$ $0.3 \% \mathrm{Si}-2.0 \% \mathrm{Mn}-0.001 \% \mathrm{~S}-0.01 \% \mathrm{Ti}-0.01 \% \mathrm{O}$ である。 なお, 母材や溶接金属のO濃度に相当する $0.001 \% \mathrm{O}$ で計 算した場合, Ti酸化物と $\mathrm{MnS}$ が生成したが, Si-Mn酸化物 は生成せず, Fig.3に示した溶接金属中の酸化物と一致しな
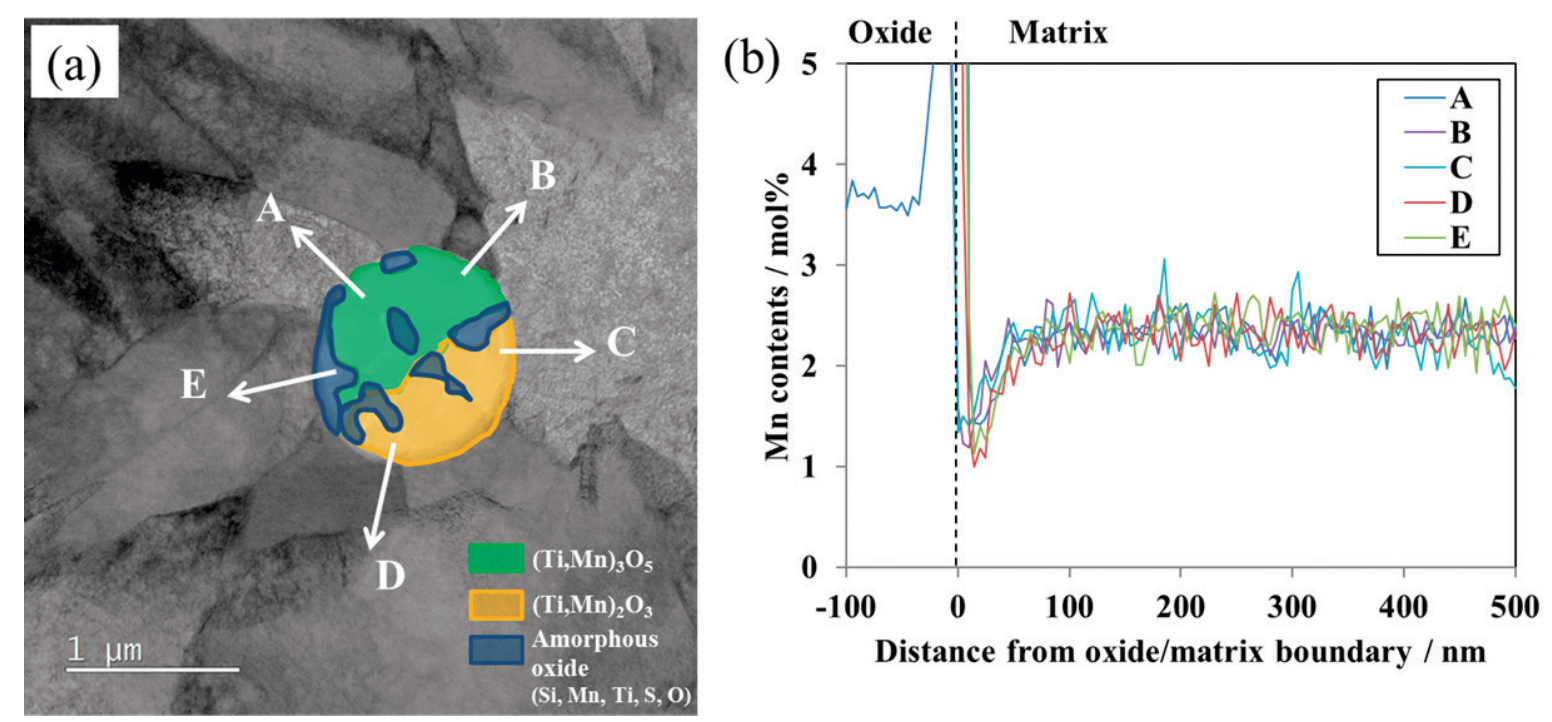

Fig. 6. Mn contents adjacent to oxide in M1 specimen. (a) Bright field image and (b) distributions of Mn contents. (Online version in color.) 
かった。熱力学計算の目的は冷却過程で形成する酸化物相 の種類とその生成順序を把握することであるため, 本研究 においては実際の観察結果に近い酸化物相を再現可能な $\mathrm{O}$ 濃度である $0.01 \%$ で計算した。Fig.9 (a) は各安定相の生成 量と温度の関係を示しており, 横軸は温度 $(\mathrm{K})$, 縦軸は各 相の生成量 (mole) である。罒中に示す $\mathrm{T}_{\mathrm{L}}, \mathrm{T}_{\mathrm{S}}$ はそれぞれ 母相の液相線温度と固相線温度である。 $\mathrm{T}_{\mathrm{L}}(1789 \mathrm{~K})$ より 低温ではSlag が安定相である。Slagは液相酸化物 (Si, Mn,
$\mathrm{Ti}, \mathrm{S}$ を含有）であり $1450 \mathrm{~K}$ 付近で凝固し, それより低温側 では $\mathrm{MnSiO}_{3}$ と $\mathrm{MnS}$ が安定相になる。一方, $\mathrm{Ti}$ 酸化物に関 しては $1742 \mathrm{~K} て ゙ ~(\mathrm{Ti}, \mathrm{Mn})_{2} \mathrm{O}_{3}$ が一時的に安定化するが, 1736 $\mathrm{K}$ ですぐに消失し， $1736 \mathrm{~K} て ゙ は ~(\mathrm{Ti}, \mathrm{Mn})_{3} \mathrm{O}_{5}$ が安定相となる。 $1700 \mathrm{~K}$ 付近の $\mathrm{Ti}$ 酸化物の安定相は $(\mathrm{Ti}, \mathrm{Mn})_{3} \mathrm{O}_{5}$ であり, 温度 の低下に伴い生成量は増加する。温度の低下に伴い $1072 \mathrm{~K}$ では $(\mathrm{Ti}, \mathrm{Mn})_{3} \mathrm{O}_{5}$ に代わり $(\mathrm{Ti}, \mathrm{Mn})_{2} \mathrm{O}_{3}$ が安定相となる。Fig.9 (b) に各相に含まれる $\mathrm{Mn}$ 濃度 ( $\mathrm{mol} \%$ ) と温度 $(\mathrm{K})$ との関
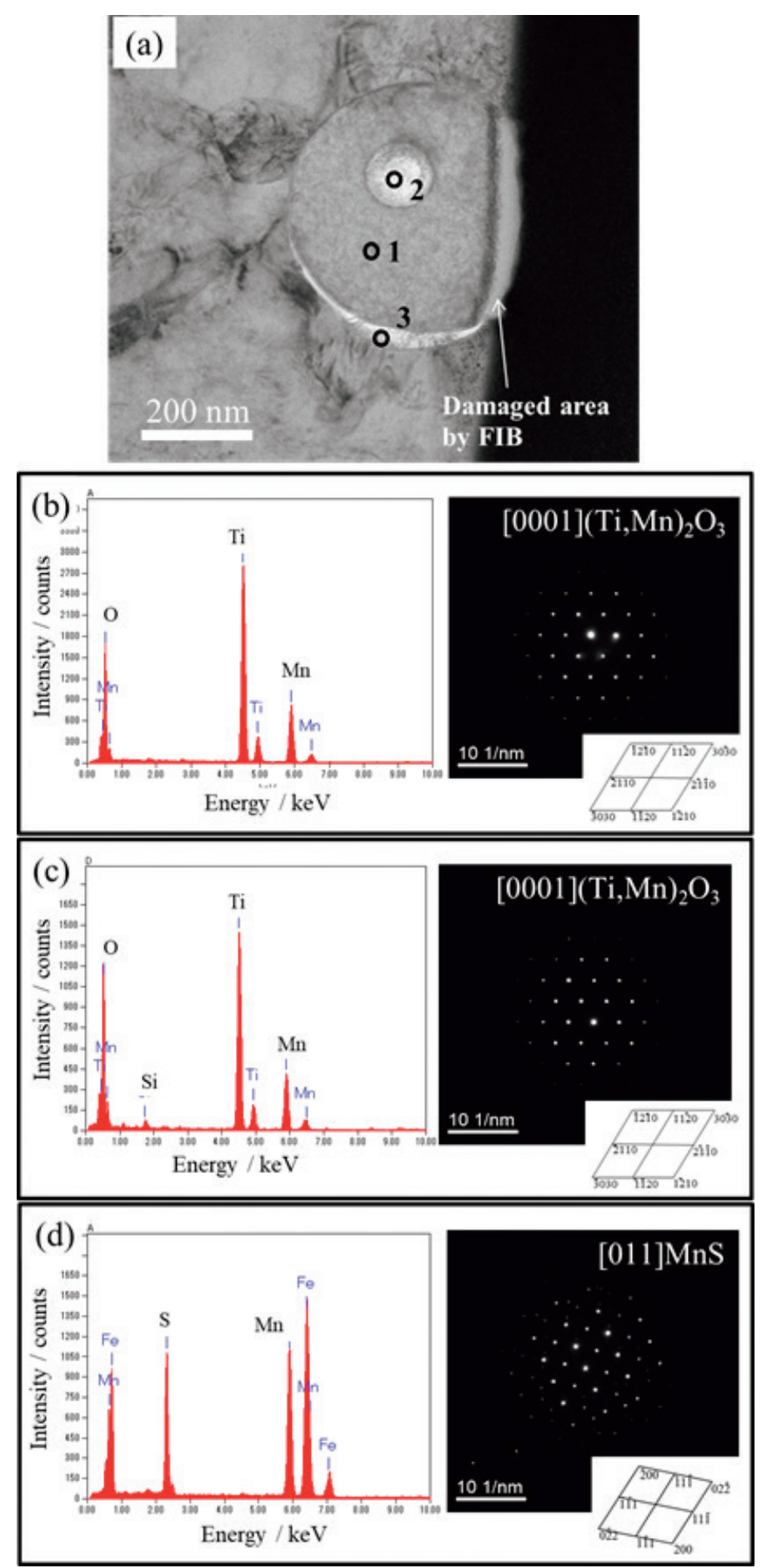

Fig. 7. TEM image and analysis of oxide in M2 specimen. (a) Bright field image, (b) EDS analysis and diffraction pattern of point 1 , (c) EDS analysis and diffraction pattern of point 2 and (d) EDS analysis and diffraction pattern of point 3. (Online version in color.) 
係を示す。1700 K 付近での Slagの平衡 Mn濃度は $16 \mathrm{~mol} \%$, $(\mathrm{Ti}, \mathrm{Mn})_{3} \mathrm{O}_{5}$ の平衡 $\mathrm{Mn}$ 濃度は $3 \mathrm{~mol} \%$ であり，いずれも母相 の平衡 $\mathrm{Mn}$ 濃度である $2 \mathrm{~mol} \%$ よりも高い。これらの酸化物 は温度の低下とともに平衡 $\mathrm{Mn}$ 濃度が増加する。低温で安 定相となる $(\mathrm{Ti}, \mathrm{Mn})_{2} \mathrm{O}_{3}$ の平衡 $\mathrm{Mn}$ 濃度は $19 \mathrm{~mol} \%$ であり， $(\mathrm{Ti}, \mathrm{Mn})_{3} \mathrm{O}_{5}$ よりも遙かに高濃度に Mnを含有する。

Fig.4に示した高温部 $(1720 \mathrm{~K})$ の観察結果より, 複合酸 化物は $(\mathrm{Ti}, \mathrm{Mn})_{3} \mathrm{O}_{5},(\mathrm{Ti}, \mathrm{Mn})_{2} \mathrm{O}_{3}$, 非晶質 $\mathrm{Si}-\mathrm{Mn}$ 酸化物（微量 の Ti， $\mathrm{Al}, \mathrm{S}$ を含む) から構成されている。これにFig.9の熱 力学計算結果を考慮して $1720 \mathrm{~K}$ の液体 $\mathrm{Sn}$ 急冷開始時点で の複合酸化物の状態を検討する。最も高温ではSlagが存在 し, 冷却過程で $1742 \mathrm{~K} て ゙(\mathrm{Ti}, \mathrm{Mn})_{2} \mathrm{O}_{3}$ が一時的に生成するが すぐに消失して $1736 \mathrm{~K}$ で $(\mathrm{Ti}, \mathrm{Mn})_{3} \mathrm{O}_{5}$ が安定となる。その後 $(\mathrm{Ti}, \mathrm{Mn})_{3} \mathrm{O}_{5}$ が成長し，1479 Kで MnS が生成，1455 K で Slag が凝固して Si-Mn酸化物となる。さらに $(\mathrm{Ti}, \mathrm{Mn})_{3} \mathrm{O}_{5}$ は 1072 $\mathrm{K}$ で $(\mathrm{Ti}, \mathrm{Mn})_{2} \mathrm{O}_{3}$ に変化する。以上より $1720 \mathrm{~K}$ の液体 $\mathrm{Sn}$ 急 冷開始時点では Slag と $(\mathrm{Ti}, \mathrm{Mn})_{3} \mathrm{O}_{5}$ が存在していたと考えら
れる。Slagは急冷過程で凝固して非晶質 Si-Mn酸化物が生 成したと考えられる。一方， $(\mathrm{Ti}, \mathrm{Mn})_{3} \mathrm{O}_{5}$ は通常の溶接金属 では $(\mathrm{Ti}, \mathrm{Mn})_{2} \mathrm{O}_{3}$ へ変化するため室温でこれほど広い領域で は認められない。これは急冷により $\mathrm{Mn}$ の拡散が抑制され て Mn 濃度が上昇せず， $1720 \mathrm{~K}$ の状態のまま $(\mathrm{Ti}, \mathrm{Mn})_{3} \mathrm{O}_{5}$ が 残存したと考えられる。

次に $(\mathrm{Ti}, \mathrm{Mn})_{2} \mathrm{O}_{3}$ の $1720 \mathrm{~K}$ での状態を検討する。Fig.4 (c) の点2で示す $(\mathrm{Ti}, \mathrm{Mn})_{2} \mathrm{O}_{3}$ が認められた領域は, Fig.4 (b) の 点 1 で示す $(\mathrm{Ti}, \mathrm{Mn})_{3} \mathrm{O}_{5}$ よりも $\mathrm{Mn}$ が明らかに高く検出され ているため, 液体 $\mathrm{Sn}$ 急冷開始時点の $1720 \mathrm{~K}$ で $(\mathrm{Ti}, \mathrm{Mn})_{3} \mathrm{O}_{5}$ とは別の相として存在していた可能性が高い。したがっ て, $1720 \mathrm{~K}$ で同領域は, Slag として存在しており急冷過程 で $\mathrm{Si}$ と Tiが分配して非晶質 $\mathrm{Si}-\mathrm{Mn}$ 酸化物と $(\mathrm{Ti}, \mathrm{Mn})_{2} \mathrm{O}_{3}$ が 生成した可能性と, $(\mathrm{Ti}, \mathrm{Mn})_{2} \mathrm{O}_{3}$ として既に存在していた可 能性の2つが考えられる。前者の可能性については急冷過 程で SiやTiが分配可能なのか, 今後さらに検討する必要 がある。後者の可能性については, Fig.9において一時的で
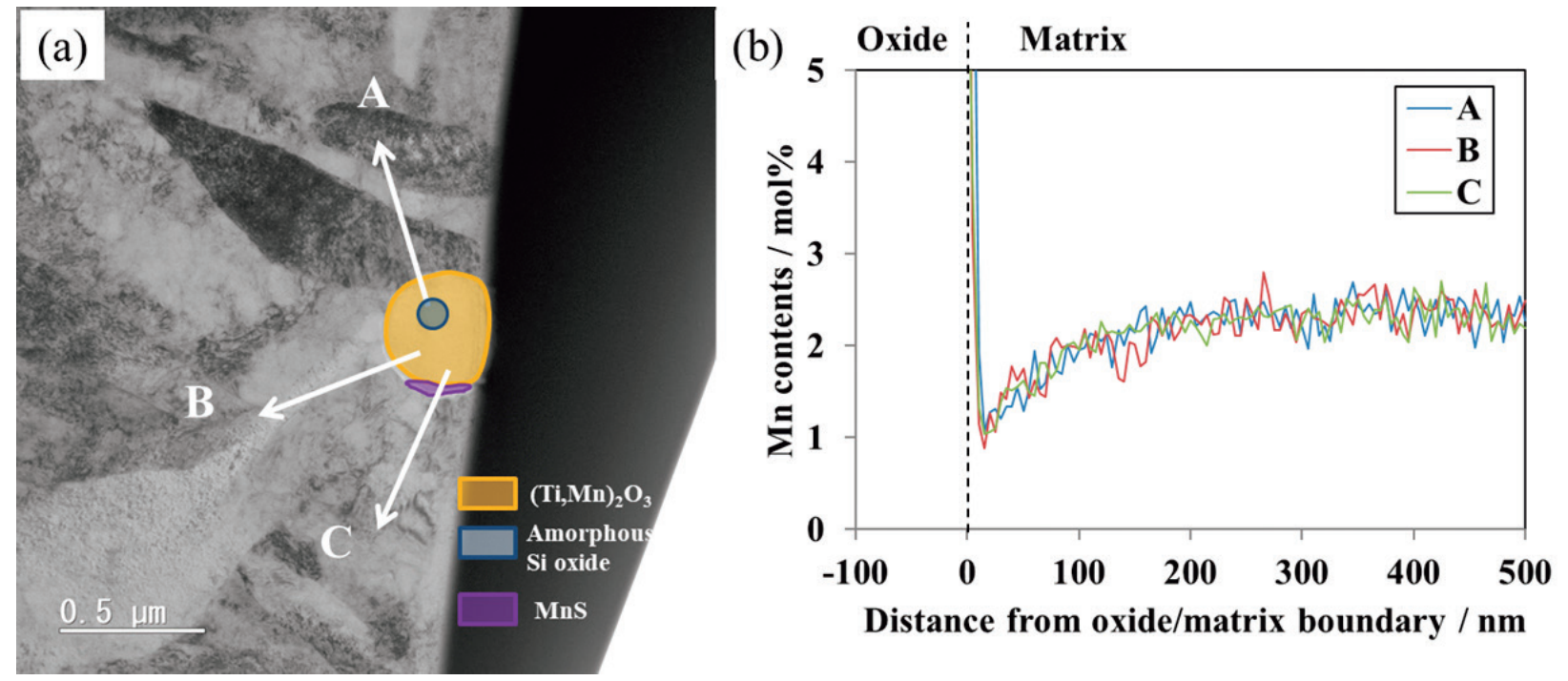

Fig. 8. Mn contents adjacent to oxide in M2 specimen. (a) Bright field image and (b) distributions of Mn contents. (Online version in color.)

(a)

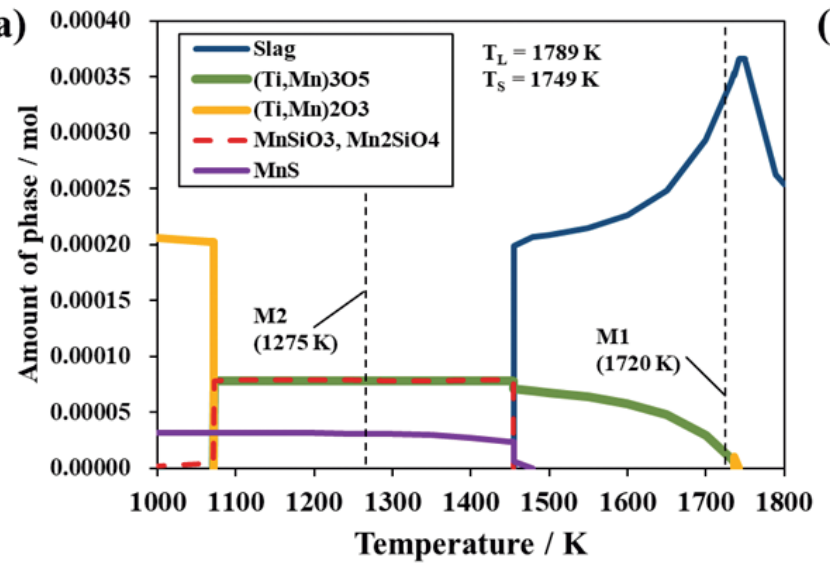

(b)

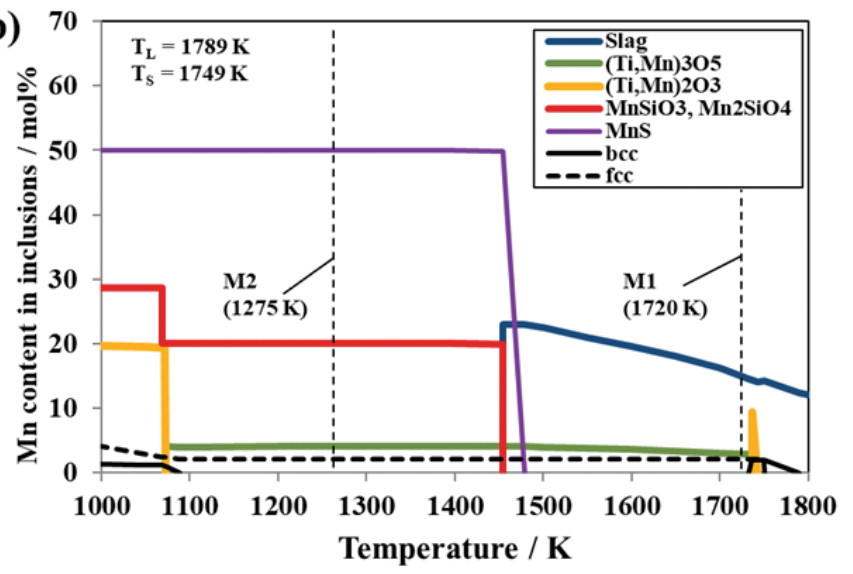

Fig. 9. Calculated contents of stable phases and Mn contents of each phase in weld metal. (a) Temperature variations of the content of each stable phase and (b) temperature variations of the Mn content of each stable phase. (Online version in color.) 
はあるが $(\mathrm{Ti}, \mathrm{Mn})_{3} \mathrm{O}_{5}$ よりも高温で $(\mathrm{Ti}, \mathrm{Mn})_{2} \mathrm{O}_{3}$ が安定相と なるように, $\mathrm{Ti}, \mathrm{Mn}, \mathrm{O}$ バランスと温度により $(\mathrm{Ti}, \mathrm{Mn})_{3} \mathrm{O}_{5}$ と $(\mathrm{Ti}, \mathrm{Mn})_{2} \mathrm{O}_{3}$ の安定性が複雑に変化することが知られてい

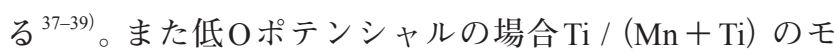
ル比により $1773 \mathrm{~K}$ 超でも $(\mathrm{Ti}, \mathrm{Mn})_{2} \mathrm{O}_{3}$ が安定となる場合も ある ${ }^{40,41)}$ 。これらのことから, 本研究のような低 $\mathrm{O} の$ 溶接 金属中では $1720 \mathrm{~K}$ で $(\mathrm{Ti}, \mathrm{Mn})_{2} \mathrm{O}_{3}$ が存在していた可能性が 考えられる。

低温部 $(1275 \mathrm{~K})$ ではFig.7で示すように $(\mathrm{Ti}, \mathrm{Mn})_{2} \mathrm{O}_{3}$ を主 体に微量の MnS や非晶質 Si 酸化物が認められた。計算上 で安定相である $(\mathrm{Ti}, \mathrm{Mn})_{3} \mathrm{O}_{5}$ が存在しないのは, 上述したよ うに低Oでは熱力学計算結果よりも高温で $(\mathrm{Ti}, \mathrm{Mn})_{2} \mathrm{O}_{3}$ が安 定相となりやすいためであると考えられる。また $\mathrm{MnS}$ は液 相酸化物 $(\mathrm{Si}, \mathrm{Mn}, \mathrm{Ti}, \mathrm{S}$ を含有) 中に含まれる Mnと S が析 出したものと考えられる。MnS はFig.9 (a) に示すように液 相酸化物 ( $\mathrm{Si}, \mathrm{Mn}, \mathrm{Ti}, \mathrm{S}$ を含有) の凝固温度より僅かに高 温で生成するため, $\mathrm{MnS}$ の生成により非晶質酸化物中の $\mathrm{Mn}$ 濃度が低下し, 残部が非晶質 Si 酸化物となると思われる。

以上をまとめると, $1720 \mathrm{~K} て ゙ は ~(\mathrm{Ti}, \mathrm{Mn})_{3} \mathrm{O}_{5},(\mathrm{Ti}, \mathrm{Mn})_{2} \mathrm{O}_{3}$, 液相酸化物 $(\mathrm{Si}, \mathrm{Mn}, \mathrm{Ti}, \mathrm{S}$ を含有) の複合酸化物が存在し ており，1275 Kでは $(\mathrm{Ti}, \mathrm{Mn})_{2} \mathrm{O}_{3}, \mathrm{MnS}$ ，非晶質 $\mathrm{Si}$ 酸化物の 複合酸化物が存在すると推察される。各相は母相よりも 高濃度にMnを含有しており, 冷却過程において平衡 $\mathrm{Mn}$ 濃度が増加する。加えて $1720 \mathrm{~K}$ から $1275 \mathrm{~K} へ$ の冷却過 程においては主要な Ti酸化物の安定相が $(\mathrm{Ti}, \mathrm{Mn})_{3} \mathrm{O}_{5}$ から $(\mathrm{Ti}, \mathrm{Mn})_{2} \mathrm{O}_{3}$ へ変化し, これに伴い $\mathrm{Ti}$ 酸化物の平衡 $\mathrm{Mn}$ 濃度 は増加する。

\section{$4 \cdot 2$ 溶接金属中のMn 欠乏層形成過程}

Fig.6に示したように高温部 $(1720 \mathrm{~K})$ では5箇所の測定 位置のいずれにおいても幅 $80 \mathrm{~nm}$ 程度の MDZが同様に観 察された。すなわち, 固相線以下での冷却過程で酸化物の 種類に関係なく複合酸化物の周囲全体にMDZが形成した と考えられる。各測定位置には $(\mathrm{Ti}, \mathrm{Mn})_{3} \mathrm{O}_{5},(\mathrm{Ti}, \mathrm{Mn})_{2} \mathrm{O}_{3}$, 非 晶質酸化物 $(\mathrm{Si}, \mathrm{Mn}, \mathrm{Ti}, \mathrm{S}$ を含有) が存在しており,いず れの酸化物も Fig.9 (b) に示すように冷却過程で平衡 Mn濃 度が増加することから, 冷却過程で母相から各酸化物へ Mnが拡散し, 酸化物/母相界面の母相側にMDZが形成し たと考えられる。それぞれ別の研究となるが $(\mathrm{Ti}, \mathrm{Mn})_{3} \mathrm{O}_{5}{ }^{42)}$, $(\mathrm{Ti}, \mathrm{Mn})_{2} \mathrm{O}_{3}{ }^{22,28,29,43-45)}$, 非晶質 $\mathrm{Si}-\mathrm{Mn}$ 酸化物 ${ }^{20,30)}$ の周囲で生じ るMDZが報告されていることからも，これらの酸化物が 複合した高温部 $(1720 \mathrm{~K})$ の複合酸化物の周囲においても 同様にMDZが形成したと考えられる。なお，母相に隣接す る酸化物の種類により Mn濃度分布の差が殆ど無い理由と しては, $1720 \mathrm{~K}$ 付近の高温域では Mnの拡散速度も比較的 速く, また次節で示すようにMDZの形成は母相の Mn 拡散 律則と考えられるため酸化物の平衡 $\mathrm{Mn}$ 濃度の影響が生じ にくいと推察される。

低温部 $(1275 \mathrm{~K})$ ではFig.8に示したように幅 $200 \mathrm{~nm}$ 程度
の明瞭なMDZが観察された。すなわち $1720 \mathrm{~K}$ から $1275 \mathrm{~K}$ の冷却中にMDZ幅は拡大した。ところで酸化物上の MnS 成長により MDZが形成する機構では，母相から MnSへ Mn が拡散し酸化物/母相界面の母相側にMDZが形成する ${ }^{24)}$ 。 $\mathrm{MnS}$ の成長が停止すると, 母相から $\mathrm{MnS} へ$ のnの拡散も 停止するが, その後, 母相から MDZへのMnの拡散は継続 するため酸化物/母相界面の母相側の $\mathrm{Mn}$ 濃度は平衡濃度

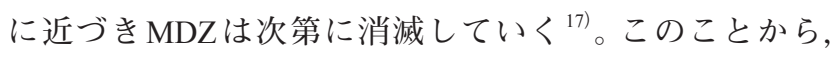
MDZ幅が拡大するためには, $1720 \mathrm{~K}$ から $1275 \mathrm{~K}$ の冷却過 程で母相から酸化物へMnの拡散が継続する必要がある。 $1720 \mathrm{~K}$ 付近で大きな割合を占める $(\mathrm{Ti}, \mathrm{Mn})_{3} \mathrm{O}_{5}$ の平衡 $\mathrm{Mn}$ 濃 度は $1500 \mathrm{~K}$ 以下では殆ど増加しない，またその後生成する $\mathrm{MnS}$ や非晶質 Si 酸化物は複合酸化物における割合が僅か である。一方, Oyaらなどの実験により $(\mathrm{Ti}, \mathrm{Mn})_{2} \mathrm{O}_{3}$ 中の平 衡 $\mathrm{Mn}$ 濃度は低温で増加することが確認されている ${ }^{43)}$ 。加 えて $1720 \mathrm{~K}$ で存在する平衡 $\mathrm{Mn}$ 濃度の低い $(\mathrm{Ti}, \mathrm{Mn})_{3} \mathrm{O}_{5}$ が, $1275 \mathrm{~K}$ への冷却過程で減少し, その代わりに平衡 $\mathrm{Mn}$ 濃度 の多い $(\mathrm{Ti}, \mathrm{Mn})_{2} \mathrm{O}_{3}$ が増加する。これらことから, $1720 \mathrm{~K}$ か ら $1275 \mathrm{~K} へ$ の冷却過程に拈いては, 母相から平衡 Mn 濃度 が高い $(\mathrm{Ti}, \mathrm{Mn})_{2} \mathrm{O}_{3}$ への拡散が継続し, MDZが形成されると 推察される ${ }^{38)}$ 。このように $(\mathrm{Ti}, \mathrm{Mn})_{3} \mathrm{O}_{5}$ から $(\mathrm{Ti}, \mathrm{Mn})_{2} \mathrm{O}_{3}$ への 相変化も MDZの形成を促進すると考えられる。以上のこ とから, $1720 \mathrm{~K}$ から $1275 \mathrm{~K}$ への冷却過程でMDZ幅が拡大 した理由は, 平衡 $\mathrm{Mn}$ 濃度の高い $(\mathrm{Ti}, \mathrm{Mn})_{2} \mathrm{O}_{3}$ の生成量が増 すことにより, 酸化物/母相界面で母相から複合酸化物へ の多量の Mnの拡散が生じたためと考えられる。

\section{$4 \cdot 3$ 冷却過程での Mn 欠乏層形成の計算}

前節の考察より, MDZは酸化物上の MnSの生成を必ず しも必要とせず，母相から酸化物へ Mnの拡散が進むこ とにより形成されると考えられる。Shigesatoらは母相か ら MnSへの Mn 拡散による MDZの形成を計算し, $1373 \mathrm{~K}$, $100 \mathrm{~s}$ 保持時にオーステナイト中の初期 Mn 濃度 $1.5 \mathrm{mass} \%$ に対して母相/ $\mathrm{MnS}$ 界面での $\mathrm{Mn}$ 濃度の低下量が 0.3 mass $\%$ に達することを示しており ${ }^{17)}$, 酸化物上の $\mathrm{MnS}$ 生成により 生じるMDZについてはいくつかの計算例が存在する ${ }^{15,16)}$ 。 一方, 本研究に打いて主な MDZ形成機構と考えられる $\mathrm{MnS}$ の生成が無い場合に酸化物/母相界面で生じる $\mathrm{MDZ}$ については計算による検証例がない。そこで本節では, 母 相から $(\mathrm{Ti}, \mathrm{Mn})_{2} \mathrm{O}_{3}$ への Mnの拡散を仮定した数值計算によ り酸化物/母相界面でのMDZ形成可否について検討した。 Fig.10 (a) に計算モデルの概略図を示す。なお計算ではモ デルの単純化のため下記の仮定を行った。

(a) 酸化物は半径 $0.5 \mu \mathrm{m}$ の球とし, オーステナイト $(\gamma)$ 中 に均一に分散していると仮定する。

（b）酸化物の核生成, 成長は考えない。厳密には冷却過程 でオーステナイト中 $\mathrm{O}$ 濃度は低下して酸化物が成長す るが, $10^{-6} \mathrm{~mol} \%$ オーダーの $\mathrm{O}$ 濃度変化であるためこ のような仮定とする。すなわち酸化物/オーステナイ 
ト界面の位置は一定であり, 冷却中の酸化物中の Mn 濃度変化のみを考える。

(c) 酸化物/オーステナイト界面では常に平衡条件が成立 するものと仮定する。

（d）酸化物の組成変化に起因する $\mathrm{Mn}$ の濃度勾配は粒子半 径方向，すなわち酸化物中心を原点と考えたときの球 座標表示における法線方向のみにあるとする。

(e) Mnの拡散は上記方向に対する拡散方程式を界面組成 で与えられる境界条件を考慮しながら差分法を用いて 数值計算する。

（f）オーステナイト中での Ti は常に平衡状態に保たれてい ると仮定する。観察結果では酸化物/オーステナイト 界面でTiの欠乏層は形成されていないことからこのよ うな仮定は妥当である。

$\mathrm{Ti}$ と $\mathrm{Mn}$ のオーステナイト中での平衡固溶量は $(\mathrm{Ti}, \mathrm{Mn})_{2} \mathrm{O}_{3} /$ オーステナイト間の Mn 分配挙動を実験的に示したOya ら の研究 ${ }^{46)}$ を参考に式 (2), 式 (3) で示す溶解度積で計算し た。

$$
\begin{aligned}
& \log K^{\prime}=\frac{1250}{T}-3.9 \cdots \cdots \\
& K^{\prime}=\frac{X_{T i}^{\gamma} \cdot X_{M n 0.5 T i 0.501 .5}^{2}}{X_{M n}^{\gamma}}
\end{aligned}
$$

$T$ : 絶対温度 $(\mathrm{K}), X_{T i}^{\gamma}$ :オーステナイト中の $\mathrm{Ti}$ 濃度 $(\mathrm{mol} \%), X_{M n}^{\gamma}$ :オーステナイト中の $\mathrm{Mn}$ 濃度 $(\mathrm{mol} \%)$, $X_{M n 0.5 T i 0.501 .5}^{2}:(\mathrm{Ti}, \mathrm{Mn})_{2} \mathrm{O}_{3}$ の濃度 $(\mathrm{mol} \%)$

オーステナイト中の $\mathrm{Ti}$ と Mnの拡散係数は以下の式 $(4)^{47)}$, 式 $(5)^{47)}$ とする。

$$
\begin{aligned}
& D_{T i}^{\gamma}=0.15 \times 10^{-4} \cdot \exp \left(-231 \times 10^{3} / R T\right) \cdots \cdots \\
& D_{M n}^{\gamma}=0.178 \times 10^{-4} \cdot \exp \left(-264 \times 10^{3} / R T\right) \cdots
\end{aligned}
$$

$D_{T i}^{\gamma}$ :オーステナイト中の $\mathrm{Ti}$ の拡散係数 $\left(\mathrm{m}^{2} / \mathrm{s}\right), D_{M n}^{\gamma}$ :オー ステナイト中の $\mathrm{Mn}$ の拡散係数 $\left(\mathrm{m}^{2} / \mathrm{s}\right), R$ : ガス定数 $(\mathrm{J} /$ $\mathrm{Mol} \cdot \mathrm{K})$

オーステナイト中の Mn 濃度の変化は式 (6) に示す球座 標法線方向の拡散方程式により計算した。

$$
\frac{\partial X_{M n}^{\gamma}}{\partial \mathrm{t}}=D_{M n}^{\gamma} \frac{\partial^{2} X_{M n}^{\gamma}}{\partial r^{2}}+\frac{2}{r} \cdot \frac{\partial X_{M n}^{\gamma}}{\partial \mathrm{r}}
$$

$t:$ 時間 $(\mathrm{s}), r:$ 法線方向の距離 $(\mu \mathrm{m})$

式（6）を $t$ について前進差分を取り, $r$ について中心差分 をとると式 (7) に示す差分形式にに展開できる。

$$
\begin{aligned}
& X(r, t+\Delta t)=X(r, t) \\
& +\Delta r \cdot D_{M n}\left\{\begin{array}{l}
\frac{X(r+\Delta r, t)-2 X(r, t)+X(r-\Delta r, t)}{\Delta r^{2}} \\
+\frac{2}{r} \cdot \frac{X(r+\Delta r, t)-X(r-\Delta r, t)}{2 \Delta r}
\end{array}\right\}
\end{aligned}
$$

$\Delta t:$ 時間の刻み量 $(\mathrm{s}), \Delta r: r$ 方向の刻み量 $(\mu \mathrm{m})$

初期条件を $1773 \mathrm{~K}, 2$ mass\% Mn-0.01 mass\% Ti, $\Delta r=$ $0.03, \Delta t=0.015$ とし, $1273 \mathrm{~K}$ まで連続冷却したときの オーステナイト中の Mn 濃度を計算した。冷却速度はレー ザ溶接金属の冷却速度に近い $20 \mathrm{~K} / \mathrm{s}$ とした。Fig.10 (b) に $1773 \mathrm{~K}$ から各温度に連続冷却した場合の計算結果を示 す。縦軸はオーステナイト中の $\mathrm{Mn}$ 濃度 $(\mathrm{mol} \%)$, 横軸は $(\mathrm{Ti}, \mathrm{Mn})_{2} \mathrm{O}_{3} /$ オーステナイト界面を原点としてオーステナ イト側への距離 $(\mu \mathrm{m})$ を示す。 $(\mathrm{Ti}, \mathrm{Mn})_{2} \mathrm{O}_{3} /$ オーステナイト 界面の Mn濃度は $1773 \mathrm{~K}$ での $2.03 \mathrm{~mol} \%$ から $100 \mathrm{~K}$ 低下し た 1673 K では 1.95 mol\%にに低下する。温度が低下するのに 伴い, $(\mathrm{Ti}, \mathrm{Mn})_{2} \mathrm{O}_{3} /$ オーステナイト界面の $\mathrm{Mn}$ 濃度は徐々に 低下し，Mn濃度が低下する領域がオーステナイト側に拡 (a)

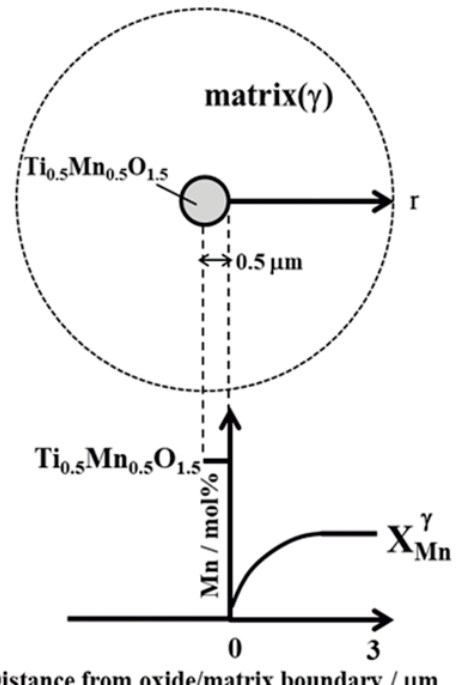

(b)

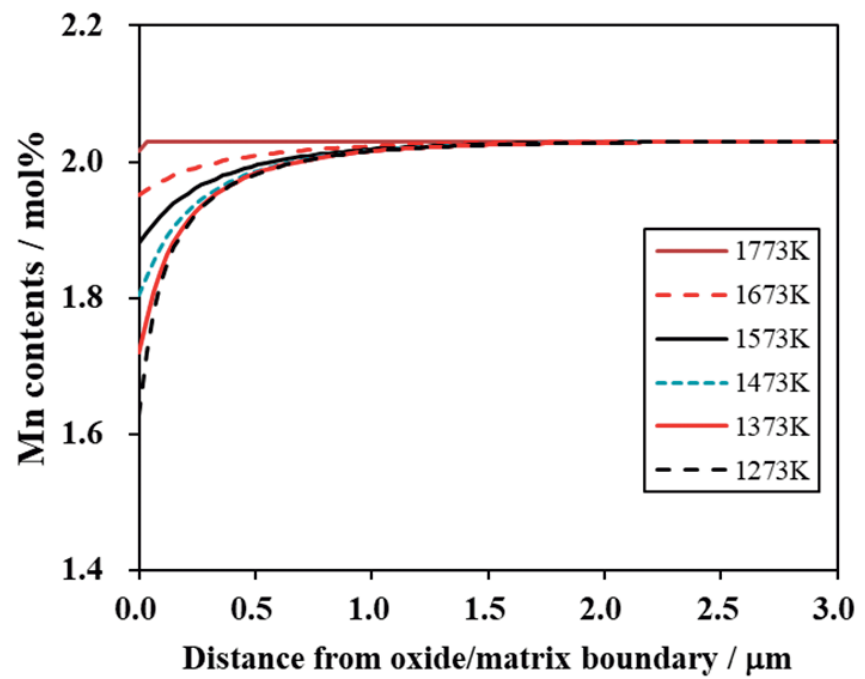

Fig. 10. Calculation of $\mathrm{Mn}$ contents in matrix $(\gamma)$ adjacent to $(\mathrm{Ti}, \mathrm{Mn})_{2} \mathrm{O}_{3}$. (a) Model for calculation and (b) calculated Mn contents in matrix continuously cooled at $20 \mathrm{~K} / \mathrm{s}$. (Online version in color.) 


\section{Mn depleted zone}

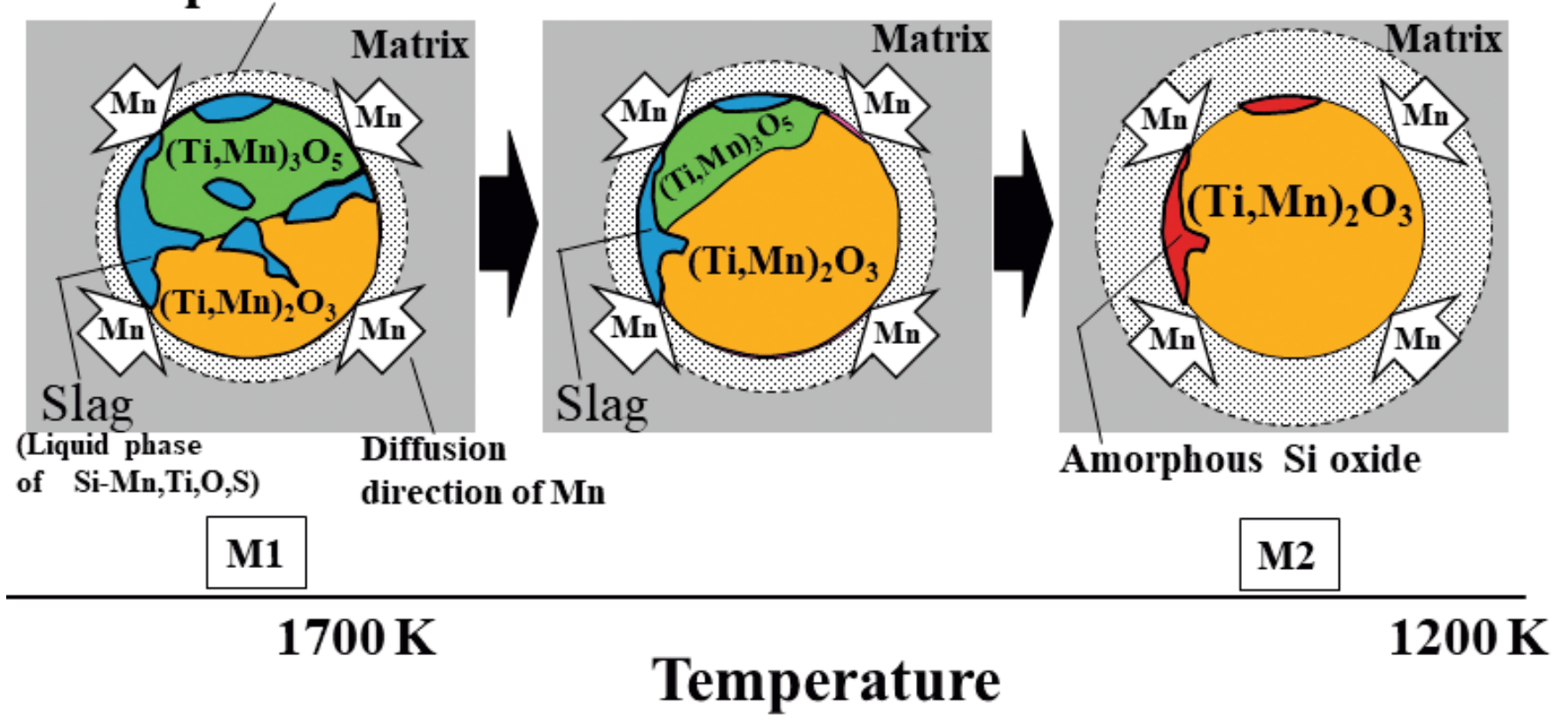

Fig. 11. Schematic illustration of formation process of oxide and Mn depletion behaviour in the oxide/matrix interface. (Online version in color.)

大していく。1273 Kでは $(\mathrm{Ti}, \mathrm{Mn})_{2} \mathrm{O}_{3} /$ オーステナイト界面 の Mn 濃度は $1.63 \mathrm{~mol} \%$ まで低下し, MDZ幅は $1 \mu \mathrm{m}$ 近くに 達する。上記仮定に基づく拡散計算により $(\mathrm{Ti}, \mathrm{Mn})_{2} \mathrm{O}_{3} /$ オー ステナイト界面で生じる MDZが冷却過程に打いて発達す る様子が再現できた。すなわち, 冷却過程の溶接金属中に おいて母相から酸化物へMnが拡散し, MDZが形成すると いうMDZ形成機構の妥当性が確認できたといえる。なお， Fig.6の高温部 $(1720 \mathrm{~K})$ で観察された MDZおよびFig.8の 低温部 $(1275 \mathrm{~K})$ で観察された MDZに比べて, Fig.10 (b) に示す計算結果ではMnの低下量は小さく, MDZの幅は大 きく算出されている。この原因として液体 $\mathrm{Sn}$ 急冷凍結法 の影響も考えられるが, 定量的な精度の向上には今回の計 算では考虑していない $(\mathrm{Ti}, \mathrm{Mn})_{3} \mathrm{O}_{5}$ や液相酸化物 $(\mathrm{Si}, \mathrm{Mn}$, $\mathrm{Ti}, \mathrm{S}$ を含有) による効果を取り入れて計算する必要がある と思われる。

以上の考察をもとにして, 本研究での低O濃度の溶接 金属の冷却過程で考えられる酸化物とMDZの形成過程 の模式図を Fig.11に示す。1700 K 付近では $(\mathrm{Ti}, \mathrm{Mn})_{3} \mathrm{O}_{5}$, $(\mathrm{Ti}, \mathrm{Mn})_{2} \mathrm{O}_{3}$, 液相酸化物 $(\mathrm{Si}, \mathrm{Mn}, \mathrm{Ti}, \mathrm{S}$ 含有 $)$ が存在する。 各酸化物の平衡 $\mathrm{Mn}$ 濃度は冷却過程で増加するため母相 から酸化物へ $\mathrm{Mn}$ の拡散が進み, これらの酸化物の周囲で $\mathrm{MDZ}$ が形成される。1700 K以下でも酸化物の平衡 $\mathrm{Mn}$ 濃度 は増加するため, 母相から酸化物へ $\mathrm{Mn}$ の拡散がさらに進 む。これに加えて, 冷却過程では $(\mathrm{Ti}, \mathrm{Mn})_{3} \mathrm{O}_{5}$ は $(\mathrm{Ti}, \mathrm{Mn})_{2} \mathrm{O}_{3}$ へ変化する。 $(\mathrm{Ti}, \mathrm{Mn})_{3} \mathrm{O}_{5}$ の平衡 $\mathrm{Mn}$ 濃度は $4 \mathrm{~mol} \%$ 程度であ るのに対し, $(\mathrm{Ti}, \mathrm{Mn})_{2} \mathrm{O}_{3}$ の平衡 $\mathrm{Mn}$ 濃度は約 $20 \mathrm{~mol} \%$ であ る。したがって $(\mathrm{Ti}, \mathrm{Mn})_{3} \mathrm{O}_{5}$ からに $(\mathrm{Ti}, \mathrm{Mn})_{2} \mathrm{O}_{3}$ に変化する 過程で母相から酸化物への Mnの拡散がさらに促進され
る。これに伴いMDZの形成が一層進むと考えられる。こ のように複合酸化物を構成する各酸化物相の平衡 $\mathrm{Mn}$ 濃 度が冷却過程で増加すること, かつ熱力学的に安定な相 が平衡 $\mathrm{Mn}$ 濃度の低い $(\mathrm{Ti}, \mathrm{Mn})_{3} \mathrm{O}_{5}$ から平衡 $\mathrm{Mn}$ 濃度の高い $(\mathrm{Ti}, \mathrm{Mn})_{2} \mathrm{O}_{3}$ に変化することにより, これを駆動力として母 相から酸化物へ Mn の拡散が生じて MDZが形成される。な お著者らがこれまで検討してきた電子ビーム溶接の低 $O$ 濃 度の溶接金属で形成される $\mathrm{MDZ}^{20,22}$ も本研究と同様の機 構により生じていると考えられる。

\section{5. 結言}

溶接時の高温状態を急冷凍結し, 低 $O$ 濃度の溶接金属中 の酸化物の構造および酸化物/母相界面で生じるMDZの形 成機構を調査した結果, 以下の結論を得た。

（1）急冷凍結試験片の観察結果から，固相線直下の $1720 \mathrm{~K}$ から急冷凍結された部位では $(\mathrm{Ti}, \mathrm{Mn})_{3} \mathrm{O}_{5},(\mathrm{Ti}, \mathrm{Mn})_{2} \mathrm{O}_{3}$, 非晶質 Si-Mn酸化物 (微量の Ti, Al, S を含む) から構 成される複合酸化物が確認され, オーステナイト/フエ ライト変態前の $1275 \mathrm{~K}$ から急冷凍結された部位では $(\mathrm{Ti}, \mathrm{Mn})_{2} \mathrm{O}_{3}$ を主体に微量の $\mathrm{MnS}$ や非晶質 $\mathrm{Si}$ 酸化物か ら構成される複合酸化物が確認された。一方, 母相と 格子整合性が良好な $\mathrm{TiO}$ などの酸化物は確認されな かった。これらの観察結果と熱力学計算の結果から, $1720 \mathrm{~K}$ では $(\mathrm{Ti}, \mathrm{Mn})_{3} \mathrm{O}_{5},(\mathrm{Ti}, \mathrm{Mn})_{2} \mathrm{O}_{3}$, 液相酸化物 $(\mathrm{Si}$, $\mathrm{Mn}, \mathrm{Ti}, \mathrm{S}$ を含有) の複合酸化物が存在し, $1275 \mathrm{~K}$ では $(\mathrm{Ti}, \mathrm{Mn})_{2} \mathrm{O}_{3}, \mathrm{MnS}$, 非晶質 $\mathrm{Si}$ 酸化物の複合酸化物が存在 
すると推察される。

(2) $1720 \mathrm{~K}$ の高温部では酸化物/母相界面の母相側に幅 80 $\mathrm{nm}$ 程度の MDZが形成される。冷却に伴いMDZの幅は 拡大し, $1275 \mathrm{~K}$ の低温部では幅 $200 \mathrm{~nm}$ 程度の MDZが 形成される。これらの MDZは酸化物の種類によらず, 複合酸化物の周囲全体に形成される。このMDZの形 成により酸化物周囲のフェライト変態が促進されると 考えられる。

（3）複合酸化物を構成する各酸化物相の平衡 $\mathrm{Mn}$ 濃度が冷 却過程で増加すること, かつ, 熱力学的に安定な相が 平衡 $\mathrm{Mn}$ 濃度の低い $(\mathrm{Ti}, \mathrm{Mn})_{3} \mathrm{O}_{5}$ から平衡 $\mathrm{Mn}$ 濃度の高い $(\mathrm{Ti}, \mathrm{Mn})_{2} \mathrm{O}_{3}$ に変化することにより, これを駆動力とし て母相から酸化物へ Mnの拡散が生じ, 複合酸化物の 周囲全体にMDZが形成されると考えられる。

（4） MnSの生成が無い場合に酸化物/母相界面で生じる $\mathrm{MDZ}$ につて, 冷却過程での $(\mathrm{Ti}, \mathrm{Mn})_{2} \mathrm{O}_{3}$ 中の $\mathrm{Mn}$ 濃度 の増加ならびに $(\mathrm{Ti}, \mathrm{Mn})_{2} \mathrm{O}_{3} /$ オーステナイト界面での $\mathrm{Mn}$ の拡散律則を仮定した拡散計算によりMDZの形成 過程が再現できた。

\section{文献}

1) Y.Ito and M.Nakanishi: J. Jpn. Weld. Soc., 44(1975), 815 (in Japanese).

2 ) N.Mori, H.Homma, S.Okita and M.Wakabayashi: J. Jpn. Weld. Soc., 50(1981), 174 (in Japanese).

3 ) A.R.Mills, G.Thewlis and J.A.Whitemen: Mater. Sci. Technol., 3(1987), 1051.

4 ) R.A.Ricks, P.R.Howell and G.S.Barritte: J. Mater. Sci., 17(1982), 732 .

5 ) S.Ohkita and Y.Horii: ISIJ Int., 35(1995), 1170.

6 ) T.Furuhara, T.Shinyoshi, G.Miyamoto, J.Yamaguchi, N.Sugita, N.Kimura, N.Takemura and T.Maki: ISIJ Int., 43(2003), 2028.

7 ) D.S.Sarma, A.V.Karasev and P.G.Jönsson: ISIJ Int., 49(2007), 1063.

8 ) O.Grong and D.K.Matlock: Int. Met. Rev., 31(1986), 27.

9 ) Y.Horii, M.Wakabayashi, S.Ohkita and M.Namura: Seitetsu Kenkyu, 327(1987), 3 (in Japanese).

10) S.S.Babu, F.Reidenbach, S.A.David, Th.Bollinghaus and H.Hoffmeister: Sci. Technol. Weld. Join., 4(1999), 63.

11) G.Thewlis: Mater. Sci. Technol., 10(1994), 110.

12) Y.Horii, K.Ichikawa, S.Ohkita, S.Funaki and N.Yurioka: Q. J. Jpn. Weld. Soc., 13(1995), 500 (in Japanese).

13) T.Yamada, H.Terasaki and Y.Komizo: Tetsu-to-Hagané, 95(2009), 65 (in Japanese).

14) Y.Okazaki, H.Ishida, K.Suenaga and T.Hidaka: Q. J. Jpn. Weld. Soc., 27(2009), 131 (in Japanese).

15) K.Yamamoto, T.Hasegawa and J.Takamura: ISIJ Int., 36(1996), 80.

16) H.Mabuchi, R.Uemori and M.Fujioka: ISIJ Int., 36(1996), 1406.
17) G.Shigesato, M.Sugiyama, S.Aihara, R.Uemori and Y.Tomita: Tetsu-to-Hagané, 87(2001), 93 (in Japanese).

18) H.S.Kim, H.-G.Lee and K.-S.Oh: Metall. Mater. Trans. A, 32(2001), 1519.

19) G.Thewlis, W.T.Chao, P.L.Harrison and A.J.Rose: Mater. Sci. Technol., 24(2008), 771.

20) R.Homma, Y.Shinohara, K.Kadoi and H.Inoue: ISIJ Int., 61(2021), 309.

21) M.Ohara and E.R.Wallach: Weld. World, 44(2000), 3.

22) R.Homma, K.Kadoi and H.Inoue: Mater. Today Commun., 29(2021), 102963.

23) Z.Xiong, S.Liu, X.Wang, C.Shang and R.D.K.Misra: Mater. Charact., 106(2015), 232.

24) S.Wako, T.Sawai and S.Mizokughi: Tetsu-to-Hagané, 78(1992), 73 (in Japanese).

25) N.Koyama, F.Tsukihashi and N.Sano: Tetsu-to-Hagané, 79(1993), 1334 (in Japanese).

26) H.S.Kim, H-G.Lee and K-S Oh: ISIJ Int., 42(2002), 1404.

27) A.Kojima, Y.Tanaka, S.Aihara, R.Uemori, Y.Terada and G.Shigesato: CAMP-ISIJ, 16(2003), 1530 (in Japanese).

28) J.M.Gregg and H.K.D.H.Bhadeshia: Metall. Mater. Trans A., 25(1994), 1603.

29) J.-S.Byun, J.-H.Shim, Y.W.Cho and D.N.Lee: Acta Mater., 51(2003), 1593.

30) K.Seo, Y.-M.Kim, H.J.Kim and C.Lee: ISIJ Int., 55(2015), 1730.

31) T.Koseki, S.Ohkita and N.Yurioka: Sci. Technol. Weld. Join., 2(1997), 65.

32) D.Wang, K.Kadoi, K.Shinozaki and M.Yamamoto: ISIJ Int., 56(2016), 2202.

33) H.Inoue, T.Koseki, S.Okita and M.Fuji: Q. J. Jpn. Weld. Soc., 15(1997), 77 (in Japanese).

34) K.Kadoi, S.Ueda, S.Tokita and H.Inoue: J. Alloy. Compd., 828(2020), 154423.

35) K.Kadoi, Y.Nakata, H.Inoue and S.Saruwatari: Mater. Charact., 165(2020), 110402.

36) C.W.Bale, P.Chartrand, S.A.Degterov, G.Eriksson, K.Hack, R.B.Mahfoud, J.Melancon, A.D.Pelton and S.Petersen: Calphad., 26(2002), 189.

37) K.Suzuki and K.Sanbongi: Tetsu-to-Hagané, 58(1972), 1594 (in Japanese).

38) Y.-B.Kang and H.-G.Lee: ISIJ Int., 50(2010), 501.

39) J.-H.Shim, Y.W.Cho, S.H.Chung, J.-D.Shim and D.N.Lee: Acta. Mater., 47(1999), 2751.

40) Y.-B.Kang I.-H.Jung and H.-G.Lee: Calphad., 30(2006), 226.

41) Y.-B.Kang I.-H.Jung and H.-G.Lee: Calphad., 30(2006), 235.

42) Q.Huang, X.Wang, M.Jiang, Z.Hu and C.Yang: Steel Res. Int., 87(2016), 445.

43) Y.Kang, J.Jang, J.H.Park and C.Lee: Met. Mater. Int., 20(2014), 119.

44) Y.Kang, K.Han, J.H.Park and C.Lee: Metall. Mater. Trans A., 46(2015), 3581.

45) Y.Hou, W.Zheng, Z.Wu, G.Li, N.Moelans, M.Guo and B.S.Khan: Acta Mater., 118(2016), 8.

46) Y.Oya, T.Yoshikawa and K.Morita: Tetsu-to-Hagané, 93(2007), 769 (in Japanese).

47) H.Oikawa: Tetsu-to-Hagané, 68(1982), 1489 (in Japanese). 